\title{
Aggregation and dissolution of aluminium oxide and copper oxide nanoparticles in natural aqueous matrixes
}

\author{
Aston F. Nanja ${ }^{1} \cdot$ Walter W. Focke $^{2} \cdot$ Ndeke Musee $^{1}$
}

Received: 21 February 2020 / Accepted: 22 May 2020 / Published online: 4 June 2020

(c) Springer Nature Switzerland AG 2020

\begin{abstract}
Aggregation and dissolution kinetics of aluminium oxide nanoparticles $\left(\mathrm{nAl}_{2} \mathrm{O}_{3}\right)$ and copper oxide nanoparticles $(\mathrm{nCuO})$ in deionised water (DIW) and freshwater sourced from two river systems were studied with the objective to understand the influencing factors. Dynamic light scattering and inductively coupled plasma mass spectrometer were used to study aggregation and dissolution, respectively. In DIW, humic acid was observed to have a concentration dependent stabilization effect on ENPs. Increasing the ionic strength destabilised the ENPs. The $\mathrm{pH}$ influenced aggregation with maximum aggregation observed at the isoelectric point. ENPs were stable in freshwater systems with HDD $<350 \mathrm{~nm}$ at $100 \mu \mathrm{g} / \mathrm{L}$. Aggregation of both ENPs was concentration dependent. The ENPs exhibited higher stability in freshwater with low, rather than high, concentrations of both natural organic matter (NOM) and electrolytes. Dissolution was higher in Elands river than in Bloubank river water. ENPs had a high tendency for dissolution at low concentrations. NOM impeded dissolution of ENPs by providing a protective coating via steric and electrostatic interaction. Released ions may have formed precipitates and chelate compounds with ligands present in freshwater especially for $\mathrm{nCuO}$ where low dissolution was apparent. These findings provide insights on aggregation and dissolution of ENPs in freshwater systems as influenced by source-specific water chemistry. Therefore, it is not possible to make generalized statement on the outcome of ENPs transformation in aquatic systems.
\end{abstract}

Keywords Aggregation kinetics $\cdot \mathrm{Al}_{2} \mathrm{O}_{3}$ nanoparticles $\cdot$ Monovalent electrolyte $\cdot \mathrm{CuO}$ nanoparticles $\cdot$ Dissolution $\cdot$ River water

\section{Introduction}

Aluminium oxide nanoparticles $\left(\mathrm{nAl}_{2} \mathrm{O}_{3}\right)$ and copper oxide nanoparticles ( $\mathrm{nCuO}$ ) are widely used engineered nanoparticles (ENPs) in consumer products and industrial applications $[44,56,57,59,60] . \mathrm{nAl}_{2} \mathrm{O}_{3}$ are widely applied in high-performance ceramics, cosmetics, packing and polishing materials, paints, and catalysts $[22,52,58,61$, $116]$. Moreover, $\mathrm{nCuO}$ are incorporated in semiconductors, cosmetics, textiles, catalysts, and pesticides [4, 21, 59, 127]. As a result, ENPs from these widespread uses are inevitably released into the environment including freshwater systems due to their incomplete removal in wastewater treatment plants $[15,48,53,77]$. In aquatic systems, ENPs can interact with biological lifeforms, and in turn, induce variant toxic effects to cellular (e.g. bacteria [44, 114], and whole organisms [68, 85, 86, 94, 111, 121, 123], Daphnia magna $[39,103,129]$, and fish $[1,9,108]$. Electronic supplementary material The online version of this article (https://doi.org/10.1007/s42452-020-2952-4) contains
supplementary material, which is available to authorized users.

\footnotetext{
$\triangle$ Aston F. Nanja, u16394152@tuks.co.za; nanjaaston@gmail.com | 1 Department of Chemical Engineering, Emerging Contaminants Ecological Risk Assessment (ECERA) Group, University of Pretoria, Hatfield, Pretoria 0028, South Africa. ${ }^{2}$ Department of Chemical Engineering, Institute of Applied Materials, University of Pretoria, Pretoria, South Africa.
} 
The observed toxic effects are dependent on exposure linked to the transformed ENPs once released into the aquatic systems $[65,67,83]$. In aquatic systems, ENPs undergo numerous transformation processes driven by the influence of their inherent intrinsic physicochemical properties (e.g. size, shape, surface chemistry, etc.) $[29,65$, 113], and exposure media chemistry like $\mathrm{pH}$, ionic strength (IS), type of natural organic matter (NOM), etc. [20, 82, 87, $99,118,122,128]$. Consequently, may lead to alteration of their behaviour, and ultimately the observed effects on biological lifeforms [75]. Among the key transformation processes of ENPs includes dissolution, adsorption, complexation, aggregation, and dispersion $[5,43,65$, $70,113]$, and consequently, strongly controls their fate and behaviour as well as bioavailability and toxic effects $[3,104,105]$. Therefore, data is needed to elucidate key controlling factors to these processes as they underpin likely exposure of ENPs in the environment by influencing their bioavailability and interactions with aquatic organisms [104]. Although such information is essential to aid improved risk assessment of ENPs; but is lacking in natural systems e.g. in river and canal waters [107].

NOM adsorption, for example, may modify surface properties of ENPs by imparting net negative surface charge; and in turn, increase their interparticle repulsions thus rendering them highly stabilized via electrostatic and steric repulsion mechanisms $[18,67,83,109]$. Additionally, different forms of humic acid (HA) in deionised water (DIW) were found to induce stabilization effect to $\mathrm{nAl}_{2} \mathrm{O}_{3}[32,74]$. The observed stability was dependent on NOM concentration (1-50 $\mathrm{mg} / \mathrm{L}$ ) and structural properties evidenced by reduction or increase in hydrodynamic diameter (HDD) $[32,74,99]$. Sousa and Teixeira [99], investigated the effect of NOM on the aggregation of $\mathrm{nCuO}$ where HA concentration $>4 \mathrm{mg} / \mathrm{L}$ was observed to induce high zeta potential $(\zeta$-potential) and low HDD; an indication of higher stabilization of the ENPs. Moreover, stabilizing effect of NOM on ENPs through enhanced dissolution and disaggregation processes may result in deleterious implications to the aquatic life e.g. increased toxicity linked to enhanced bioavailability, mobility and dispersion $[3,83,106]$.

Additionally, other exposure media chemistry parameters have been reported to influence the stability of ENPs. For example, exposure media $\mathrm{pH}$ can influence the aggregation and disaggregation by either increasing or decreasing the $\zeta$-potential of ENPs [5, 82]. Several studies have highlighted the influence of $\mathrm{pH}$ on ENPs $\zeta$-potential; where $\mathrm{pH}$ close to isoelectric point (IEP) where the $\zeta$-potential is zero, or close to zero with corresponding maximum aggregation observed, and therefore, ENPs exhibits minimal stability $[6,74,83,98]$. Other factors like IS, type and valence of the electrolytes (monovalent or divalent) also play a key role on the aggregation of $\mathrm{nCuO}[87,98,99]$, and
$\mathrm{nAl}_{2} \mathrm{O}_{3}[33,74]$. Studies on the effect of metal valence and electrolyte type on ENPs stability in aqueous media show that both monovalent and divalent cations can promote ENPs aggregation; with divalent cations exerting greater destabilization effects $[33,87]$.

Notably, stability studies outlined in the preceding paragraphs for the ENPs were carried out largely in DIW as exposure media; which does not mimic accurately the natural environment, and at higher exposure concentrations far above those expected [41, 42], or realistic environmental concentrations as estimated from modelling studies $[73,76]$, and detected in actual environmental systems (e.g. rivers) [8, 88]. For example, Sousa and Teixeira [99], used $100 \mathrm{mg} / \mathrm{L}$ of $\mathrm{nCuO}$ whereas Mui et al. [74], used up to $614 \mathrm{mg} / \mathrm{L}$ of $\mathrm{nAl}_{2} \mathrm{O}$, yet likely environmental concentrations are $<0.1 \mathrm{mg} / \mathrm{L}[10,31,49]$. To date, handful studies have investigated the stability and aggregation of $\mathrm{nAl}_{2} \mathrm{O}_{3}$ $[86]$ and on $\mathrm{nCuO}[20,40]$ in freshwater at environmentally relevant concentrations.

Thus, the aim of this study was to evaluate the transformation of ENPs at environmentally relevant concentrations in synthetic and natural water. The natural water was sourced from two hydrological zones in Gauteng and North West Provinces, South Africa as an attempt to elucidate how water chemistry parameters are likely to influence the transformation of ENPs in actual environmental matrixes e.g. freshwater. Herein, $\mathrm{nCuO}$ and $\mathrm{aAl}_{2} \mathrm{O}_{3}$ were tested because of their widespread use and high global production $[12,90]$; yet currently their fate and behaviour in aquatic systems remain largely unreported. The studies are relevant as they offer insights on the likely implications of ENPs in freshwater - an essential aspect required to support their effective risk assessment in the environmental systems.

\section{Materials and methods}

\subsection{Materials}

The nCuO (nanopowder, $<50 \mathrm{~nm}$, CAS No 1317-38-00), $\mathrm{nAl}_{2} \mathrm{O}_{3}$ (30-60 nm, $20 \mathrm{wt} \%$ in water, CAS No 1344-28-10), HA (CAS No 1415-93-6), sodium chloride (CAS No 764714-5) as well as the analytical grades of nitric acid $\left(\mathrm{HNO}_{3}\right)$, hydrochloric acid $(\mathrm{HCl})$ and sodium hydroxide $(\mathrm{NaOH})$ were all purchased from Sigma-Aldrich (Johannesburg, South Africa). All materials were used as received from the supplier.

Freshwater samples were collected from two river systems, namely: Elands River (ER) ( $25^{\circ} 32^{\prime} 58.4^{\prime \prime} \mathrm{S} 28^{\circ} 33^{\prime}$ $53.4^{\prime \prime} \mathrm{E}$ ) in Gauteng Province (South Africa), and the Bloubank River (BR) (26 $\left.01^{\prime} 20.3^{\prime \prime} \mathrm{S} 27^{\circ} 26^{\prime} 31.6^{\prime \prime} \mathrm{E}\right)$ in North West Province (South Africa).Water samples collected 
from ER had a temperature of $22^{\circ} \mathrm{C}$ and $\mathrm{pH} 8.1$ whereas in $\mathrm{BR}$ the values were $18{ }^{\circ} \mathrm{C}$ and 7.9 , respectively. Temperature values were measured on site, and samples were filtered through a $0.20 \mu \mathrm{m}$ pore size standard filter (Millipore) before storage at $4{ }^{\circ} \mathrm{C}$ prior to use. The physical and chemical compositions of river water samples are listed in Table 1.

\subsection{Characterization of ENPs}

The crystal structure of ENPs were determined using Bruker D8 Advance powder X-ray diffractometer (PXRD) with monochromatized $\mathrm{Cu}$ Ka radiation with wavelength of $1.54 \AA$. Transmission electron microscopy (TEM) (JEM 2010F, JEOL Ltd., Japan) was used to determine particle size distribution and primary morphology of $\mathrm{nCuO}$ and $\mathrm{nAl}_{2} \mathrm{O}_{3}$. In DIW and river water samples, Malvern Zetasizer Nano series (Model ZEN 3600; Malvern Instruments, UK) was used to measure the hydrodynamic diameter (HDD), and $\zeta$-potential of $n C u O$ and $\mathrm{nAl}_{2} \mathrm{O}_{3}$. Sedimentation kinetics of ENPs in DIW and freshwater was studied using ultraviolet-visible (UV-Vis) spectroscopy. Measurements were done using a $1 \mathrm{~cm}$ optical path length quartz cuvettes on the Hitachi high technology U-3900 spectrophotometer (USA). Further, the particles surface

Table 1 Characterisation of freshwater from two river systems in South Africa

\begin{tabular}{llll}
\hline Parameter & Unit & Elands river & Bloubank river \\
\hline $\mathrm{pH}$ & - & 8.1 & 7.9 \\
$\mathrm{~K}^{+}$ & $\mathrm{mg} / \mathrm{L}$ & 4.24 & 3.13 \\
$\mathrm{Na}^{+}$ & $\mathrm{mg} / \mathrm{L}$ & 15.6 & 22.4 \\
$\mathrm{Ca}^{2+}$ & $\mathrm{mg} / \mathrm{L}$ & 14.0 & 36.0 \\
$\mathrm{Cl}^{-}$ & $\mathrm{mg} / \mathrm{L}$ & 17.1 & 12.9 \\
$\mathrm{SO}_{4}{ }^{2-}$ & $\mathrm{mg} / \mathrm{L}$ & 9.03 & 6.77 \\
$\mathrm{Mg}^{2+}$ & $\mathrm{mg} / \mathrm{L}$ & 9.82 & 31.0 \\
$\mathrm{NO}_{3}{ }^{-}$ & $\mathrm{mg} / \mathrm{L}$ & 0.33 & 0.20 \\
$\mathrm{PO}_{4}{ }^{3-}$ & $\mathrm{mg} / \mathrm{L}$ & 0.57 & 1.23 \\
$\mathrm{NH}_{4}{ }^{+}$ & $\mathrm{mg} / \mathrm{L}$ & 4.27 & 3.40 \\
$\mathrm{Cu}_{\text {tot }}$ & $\mathrm{mg} / \mathrm{L}$ & $<0.002$ & $<0.002$ \\
$\mathrm{Al}_{\text {tot }}$ & $\mathrm{mg} / \mathrm{L}$ & $<0.002$ & $<0.002$ \\
$\mathrm{Fe}_{\text {tot }}$ & $\mathrm{mg} / \mathrm{L}$ & $<0.004$ & $<0.004$ \\
$\mathrm{Zn}_{\text {tot }}$ & $\mathrm{mg} / \mathrm{L}$ & 0.008 & 0.010 \\
$\mathrm{DOC}$ & $\mathrm{mg} / \mathrm{L}$ & 5.51 & 8.25 \\
$\mathrm{Alkalinity}$ & $\mathrm{mg} \mathrm{CaCO} / \mathrm{L}$ & 75.6 & 217 \\
$(\mathrm{EC}) @ 25{ }^{\circ} \mathrm{C}$ & $\mathrm{mS} / \mathrm{m}$ & 19.6 & 39.8 \\
$\mathrm{IS}$ & $\mathrm{mM}$ & 2.48 & 5.35 \\
\hline
\end{tabular}

$D O C$ dissolved organic carbon; $A I_{\text {tot }}$ total aluminium; $F e_{\text {tot }}$ total iron; $Z n_{\text {tot }}$ total zinc; $C u_{\text {tot }}$ total copper; $E C$ electrical conductivity area analysis was done following the Braunner, Emmett, and Teller (BET) theory.

\subsection{Aggregation kinetics of ENPs}

Suspensions of $\mathrm{nAl}_{2} \mathrm{O}_{3}$ and $\mathrm{nCuO}$ were prepared both in DIW or river water to make a stock concentration of $10 \mathrm{mg} / \mathrm{L}$, and thereafter, individual ENPs suspensions were sonicated for $30 \mathrm{~min}$ at $25^{\circ} \mathrm{C}$ to achieve homogeneity. From the resultant stock suspensions, dilutions were carried out to obtain lower concentrations of 0.1 and $1 \mathrm{mg} / \mathrm{L}$ of $\mathrm{nAl}_{2} \mathrm{O}_{3}$ or $\mathrm{nCuO}$. All studies were done at concentrations of $0.1,1$, and $10 \mathrm{mg} / \mathrm{L}$ over $48 \mathrm{~h}$ in both exposure media. To ensure that the introduction of ENPs had no influence on the $\mathrm{pH}$ of the exposure media during aggregation and dissolution studies, likely changes in $\mathrm{pH}$ were checked at $0,6,24$ and $48 \mathrm{~h}$. To elucidate the influence on aggregation dynamics of ENPs linked to water chemistry parameters, $\mathrm{HDD}$ were characterised at variant ranges of $\mathrm{pH}, \mathrm{NOM}$, and IS in DIW with resistivity of $18.2 \mathrm{M} \Omega \mathrm{cm}$. All aggregation kinetics were determined by dynamic light scattering (DLS) measurements to obtain information on HDD and $\zeta$-potential dynamics. All measurements were done in triplicates, and hence, herein expressed as mean and standard deviation (mean \pm SD).

The effect of $\mathrm{pH}$ was investigated from $\mathrm{pH} 3$ to 9 at very low IS (《 $0.001 \mathrm{mM})$. The $\mathrm{pH}$ of DIW was adjusted using either $\mathrm{HCl}$ or $\mathrm{NaOH}$. Effect of IS was evaluated at concentrations of 1 and $10 \mathrm{mM}$ of $\mathrm{NaCl}$, at circumneutral $\mathrm{pH}(\mathrm{pH} 7)$ as it is within the range of expected $\mathrm{pH}$ in natural aquatic systems. HA stock solutions at concentrations of 1 and $10 \mathrm{mg} / \mathrm{L}$ were prepared in DIW at $\mathrm{pH}$ 7, followed by sonication for $2 \mathrm{~h}$, and thereafter, filtered through a $0.20 \mu \mathrm{m}$ pore size filter. All stock solutions were kept at $4{ }^{\circ} \mathrm{C}$ before use. IS for water samples from each river was determined using the expression:

$\mathrm{IS}=\frac{1}{2} \sum_{i} C_{i} Z_{i}^{2}$

where IS is the ionic strength in $\mathrm{mM}, C_{i}$ is the concentration of the ith species in $\mathrm{mM}$, and $\mathrm{Z}_{\mathrm{i}}$ is the charge of the ith species. All concentration values are summarised in Table 1.

\subsection{Dissolution kinetics of ENPs}

Dissolution of $\mathrm{nAl}_{2} \mathrm{O}_{3}$ and $\mathrm{nCuO}$ was studied by preparing samples following the same procedure described in aggregation studies section. In addition, at 2 and $48 \mathrm{~h}$, samples were collected and centrifuged at $4000 \times \mathrm{g}$ for $45 \mathrm{~min}$ using $3 \mathrm{KDa}$ Amicon Ultra $15 \mathrm{~mL}$ centrifugal filters and followed by digestion using $\mathrm{HNO}_{3}$. Presence of nanoparticles (particulates) in the filtrate following filtration was 
checked using the Zetasizer. Dissolution measurements were done in triplicates using inductively coupled plasma mass spectrometer (ICP-MS) (ICPE-9820, Shimadzu, Japan).

\section{Results and discussion}

\subsection{Characterisation of ENPs}

PXRD patterns for $\mathrm{nAl}_{2} \mathrm{O}_{3}$ and $\mathrm{nCuO}$ are shown in Fig. SI.1. Results show that $\mathrm{nAl}_{2} \mathrm{O}_{3}$ had main phase (alpha) and with monoclinic structure (Fig. SI.1a). Traces of Corundum (hexagonal) as impurity were also identified implying it was a mixture of alpha $\mathrm{nAl}_{2} \mathrm{O}_{3}$ and Corundum. PXRD spectra patterns for $\mathrm{nCuO}$ revealed a single-phase (beta), and free of impurities-an indication it had a phase pure material (Fig. Sl.1b). TEM images of both $\mathrm{nAl}_{2} \mathrm{O}_{3}$ and $\mathrm{nCuO}$ (Fig. $\mathrm{SI} .2$ ) revealed that $\mathrm{nCuO}$ had a mixture of hexagonal, rods, and spherical shapes with an average size of 18-47 nm (Fig. SI.2a). The $\mathrm{nAl}_{2} \mathrm{O}_{3}$ had both spherical and hexagonal shapes with an average size of $35-55 \mathrm{~nm}$ (Fig. SI.2b). Therefore, TEM size results were within the manufacturer's specified values for each ENPs type. No peaks in UV-Vis spectroscopy were observed in the wavelength range 200 to $800 \mathrm{~nm}$ for both $\mathrm{nAl}_{2} \mathrm{O}_{3}$ and $\mathrm{nCuO}$ at the concentrations used in the study ( 0.1 and $1 \mathrm{mg} / \mathrm{L}$ ) except water absorption peak as shown for $\mathrm{nCuO}$ (Fig. Sl. 3). Similar observation have been reported from a study where 25 to $100 \mathrm{mg} / \mathrm{L}$ $\mathrm{nCuO}$ were used [40]. This is despite the technique being successfully applied for characterisation during synthesis of the ENPs where absorption maximum wavelength for $\mathrm{nAl}_{2} \mathrm{O}_{3}$ has been reported to be in the range 200 to $250 \mathrm{~nm}$ $[91,92]$ and that of $\mathrm{nCuO}$ ranges from 250 to $400 \mathrm{~nm}[28$, 79 , 97]. Based on these results, UV-Vis may not be a recommendable technique for studies involving sedimentation kinetics of the considered ENPs. However, the technique is still useful for ENPs that absorb strongly in UV-Vis region such as silver and gold nanoparticles whose detections limits are in parts per billion (ppb) $[38,95,130]$. The BET results showed that $\mathrm{nAl}_{2} \mathrm{O}_{3}\left(50.5 \mathrm{~m}^{2} / \mathrm{g}\right)$ had about 27 -fold higher surface area relative to $\mathrm{nCuO}\left(1.85 \mathrm{~m}^{2} / \mathrm{g}\right)$.

\subsection{Aggregation kinetic studies of ENPs}

\subsubsection{Effect of $\mathrm{pH}$ on ENPs aggregation}

Figure 1 shows that HDD and $\zeta$-potential were $\mathrm{pH}$ dependent (3 to 9) following exposure at different concentrations of ENPs with an isoelectric point (IEP) at around $\mathrm{pH}$ $4\left(\mathrm{pH}_{\text {IEP }}\right)$. Previously, $\mathrm{pH}_{\text {IEP }}$ values for $\mathrm{nAl}_{2} \mathrm{O}_{3}$ have been observed in $\mathrm{pH}$ range 4 to $9.6[36,50,54,55]$ depending on particles properties and exposure media characteristics; thus our findings are consistent with published literature.
At $\mathrm{pH}>\mathrm{pH}_{\text {IEP }} \zeta$-potential of $\mathrm{nAl}_{2} \mathrm{O}_{3}$ changed from positive to negative as reported elsewhere $[32,35]$. For $\mathrm{nAl}_{2} \mathrm{O}_{3}$, at $\mathrm{pH}<\mathrm{pH}_{\mathrm{IEP}}$ and highest $\mathrm{pH}$ of 9 , concentration of $0.1 \mathrm{mg} / \mathrm{L}$ had higher HDD relative to those of $1 \mathrm{mg} / \mathrm{L}$ and $10 \mathrm{mg} / \mathrm{L}$ (Fig. 1b); but no apparent trend was observed within $\mathrm{pH}$ range of $4<\mathrm{pH}<9$. The plausible reason for random HDD changes at low concentration of $0.1 \mathrm{mg} / \mathrm{L}$ is attributed to rapid aggregation and disaggregation processes linked to low $\zeta$-potential (Fig. 1a) where the electrostatic repulsion is low to negligible. However, $\zeta$-potential results show that higher concentrations of ENPs may hold higher surface charge (Fig. 1a), and hence, may explain why at $\mathrm{pH}>\mathrm{pH}_{\text {IEP }}$ $10 \mathrm{mg} / \mathrm{L}$ had the highest charge, and in turn, exhibited limited HDD changes. Results indicated that at circumneutral $\mathrm{pH}(\mathrm{pH}$ ) irrespective of ENPs exposure concentration, HDD values were $<1000 \mathrm{~nm}$; implying their likelihood to be stable in natural aquatic systems which has $\mathrm{pH}$ of 6 to 9 [14].

Similarly, $\mathrm{nCuO}$ had the highest $\mathrm{HDD}$ observed at $\mathrm{pH}_{\text {IEP }}$ of $\sim 4$ and compares well with $\mathrm{pH} 5.42$ reported by E1-Trass et al. [28]. The lowest concentration $(0.1 \mathrm{mg} / \mathrm{L})$ exhibited the highest HDD $(1552 \pm 513 \mathrm{~nm})$, and the least at $10 \mathrm{mg} / \mathrm{L}$ $(804 \pm 73 \mathrm{~nm})$ (Fig. 1d). However, although at $10 \mathrm{mg} / \mathrm{L}$ $\mathrm{nCuO}$ had the least HDD, the $\zeta$-potential results were similar across all concentrations (Fig. 1c) over $\mathrm{pH}$ range of 3 to 9; thus, $\zeta$-potential is unlikely to be the only controlling factor on aggregation in DIW under the experimental conditions investigated. Previously, similar trend has been observed where aggregation of $\mathrm{nCuO}$ increased as exposure concentration decreased $[40,99]$. This phenomenon exhibited by $\mathrm{nCuO}$ remain unclear since other soluble ENPs like $n A g$ and $n Z n O$ their aggregation in aqueous media was observed to increase with increasing concentration [104], an aspect that requires further research to elucidate the underlying mechanism(s). Hence, the stability of ENPs in aquatic environment are dependent on $\mathrm{pH}$ $[11,64]$, and the type of ENPs. Notably, pH studies were done at very low IS ( $\ll 0.001 \mathrm{mM}$, Fig. 1) to eliminate likely masking effect of IS on aggregation as $\mathrm{pH}$ was changed; hence IS was deemed too low to exert influence on the observed aggregation. No considerable changes in $\mathrm{pH}$ were observed irrespective of concentration of ENPs used or exposure time following the introduction of ENPs during aggregation studies.

To elucidate the aggregation kinetics of ENPs over time, and at relevant $\mathrm{pH}$ in actual environment; further investigations were done on $\zeta$-potential and aggregation at circumneutral pH (Fig. 2). Results showed that $\mathrm{nAl}_{2} \mathrm{O}_{3}$ had lower negative $\zeta$-potential $(-13$ and $-19 \mathrm{mV})$ at $0.1 \mathrm{mg} / \mathrm{L}$ (Fig. 2a) and stable HDD with narrow range of 664 to $794 \mathrm{~nm}(<1000 \mathrm{~nm})$ over $48 \mathrm{~h}$ (Fig. 2b). However, higher $\zeta$-potential $(-20$ and $-25 \mathrm{mV}$ ) and resultant lower HDD ranging from 370 to $450 \mathrm{~nm}$ over $48 \mathrm{~h}$ (Fig. 2b) were 


\section{$\bullet 0.1 \mathrm{mg} / \mathrm{L} \quad \Delta 1 \mathrm{mg} / \mathrm{L} \quad \square 10 \mathrm{mg} / \mathrm{L}$}
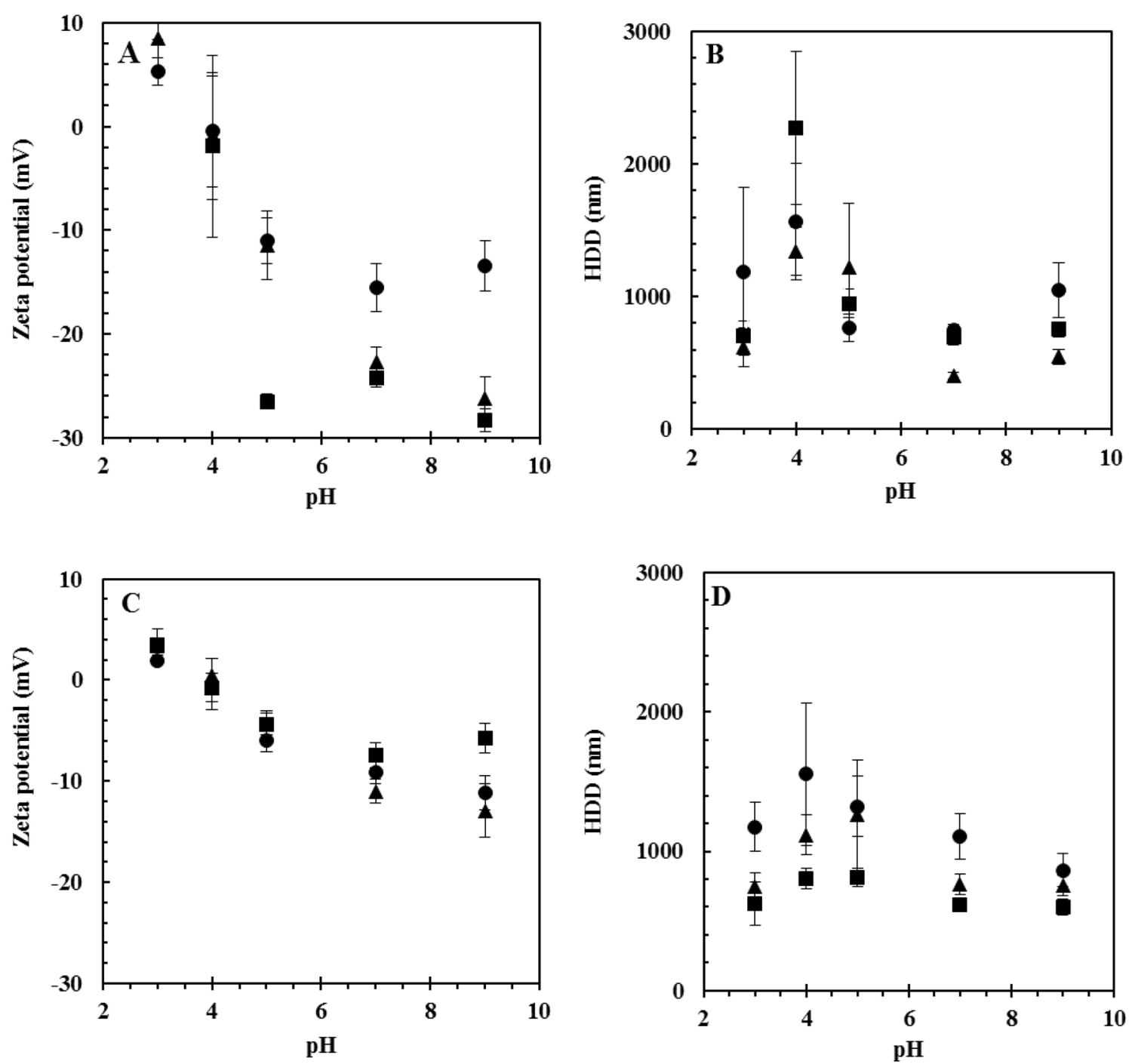

Fig. 1 -potential and $\mathrm{HDD}$ for $\mathrm{nAl}_{2} \mathrm{O}_{3}(\mathbf{a}$ and $\mathbf{b}$, respectively), and $\mathrm{nCuO}$ (c and $\mathbf{d}$, respectively) in DIW after $2 \mathrm{~h}$ with IS (0.00001-0.001 mM)

observed at $1 \mathrm{mg} / \mathrm{L}$. This implies higher concentration(s) carry higher surface charge - the electrostatic potential necessary to stabilize ENPs by limiting particle-particle interaction-and in turn, promote stability through inhibition of aggregation. Hence, increase in $\zeta$-potential resulted to low aggregation of $\mathrm{nAl}_{2} \mathrm{O}_{3}$. However, at $10 \mathrm{mg} / \mathrm{L}$ $\mathrm{nAl}_{2} \mathrm{O}_{3}$ had high aggregation although both $1 \mathrm{mg} / \mathrm{L}$ and $10 \mathrm{mg} / \mathrm{L}$ had similar $\zeta$-potential. This is because at higher concentration, high collision frequency of ENPs may have resulted to observed higher aggregation.

Due to higher solubility of $\mathrm{nCuO}[2,100]$ than $\mathrm{nAl}_{2} \mathrm{O}_{3}$ [112], results suggest that the positively charged $\mathrm{Cu}^{2+}$ may have contributed to the reduction of negative charges on $\mathrm{nCuO} \zeta$-potential. This is by increasing positive surface charge on ENPs; and in turn, lowered the $\mathrm{nCuO} \zeta$-potential
$[23,105]$. Conversely, whereas $\zeta$-potential were similar for all exposure concentrations at pH 7 (Fig. 2c as amplified on the insert) results in Fig. $2 \mathrm{~d}$ show that HDD decreased as the exposure concentration increased.

The higher HDD observed at the lowest concentration $(0.1 \mathrm{mg} / \mathrm{L})$ was plausibly due to other factors besides surface charge and size; e.g. shape that were not considered in this study, and therefore, merits further investigations. And, depending on ENPs type, agglomeration may vary considerably even at fixed $\mathrm{pH}(\mathrm{pH} 7)$, and exposure time (Fig. 2). For example, irrespective of exposure concentration, $\mathrm{HDD}$ for $\mathrm{nAl}_{2} \mathrm{O}_{3}$ was lower compared to $\mathrm{nCuO}$. The difference in aggregation was attributed to lower average-sized nCuO (18-48 nm); hence making them highly reactive (evidenced by formation of larger aggregates) 
$\bullet 0.1 \mathrm{mg} / \mathrm{L} \quad \Delta 1 \mathrm{mg} / \mathrm{L} \quad \square 10 \mathrm{mg} / \mathrm{L}$
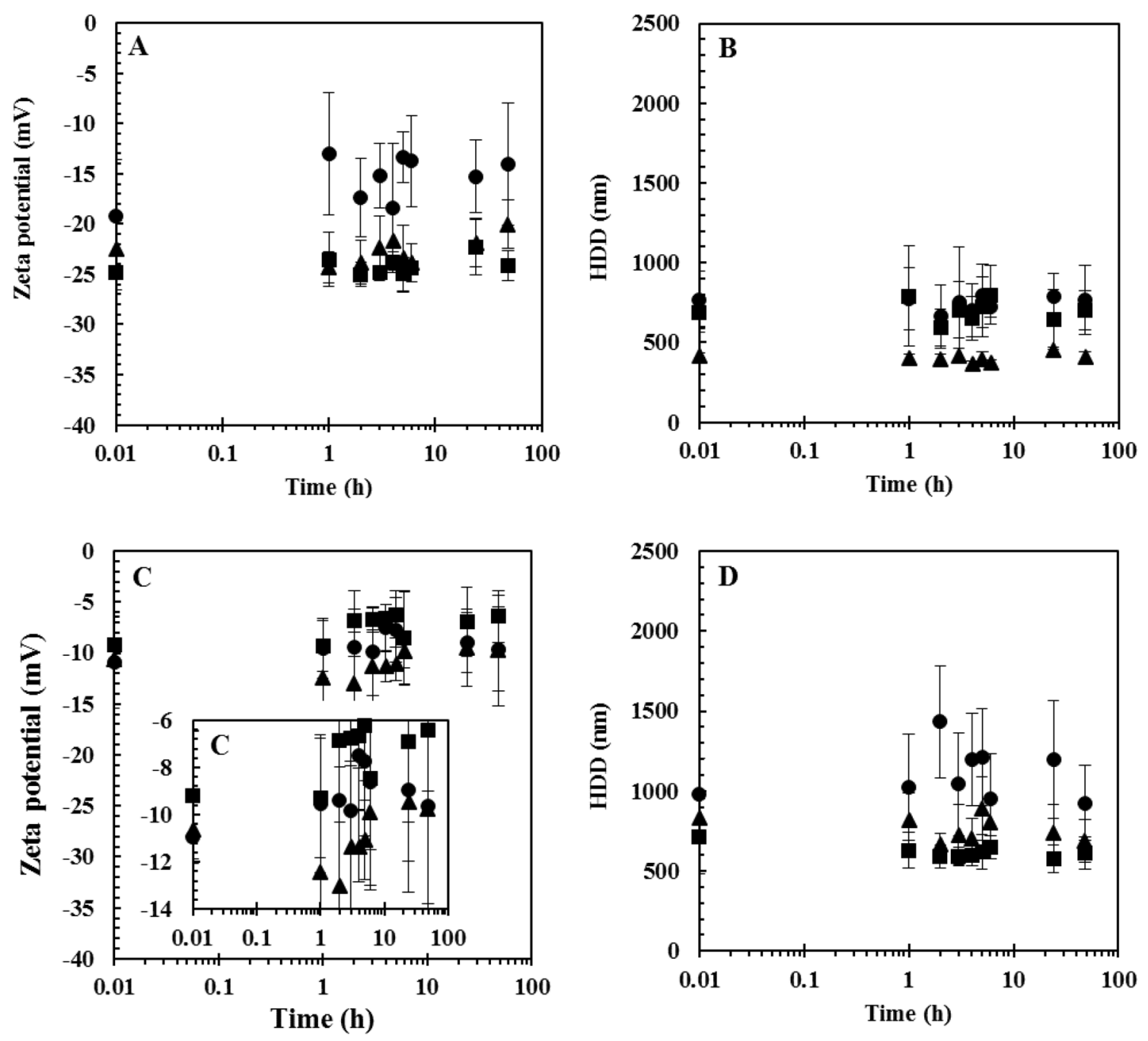

Fig. 2 -potential and $\mathrm{HDD}$ for $\mathrm{nAl}_{2} \mathrm{O}_{3}$ (a and $\mathbf{b}$, respectively), and $\mathrm{nCuO}$ (c and d, respectively) in DIW over $48 \mathrm{~h}$ at $\mathrm{pH} 7$

compared to $\mathrm{nAl}_{2} \mathrm{O}_{3}$ with larger sizes of $35-47 \mathrm{~nm}$. The influence of $\mathrm{pH}$ on aggregation of ENPs over $48 \mathrm{~h}$ at all exposure concentrations was investigated, and the results are summarised in Figs. SI. 4, 5 and 6 . Results show that at a fixed $\mathrm{pH}$, both $\zeta$-potential and HDD varied marginally over $48 \mathrm{~h}$. All $\mathrm{pH}$ values away from the $\mathrm{pH}_{\mathrm{IEP}}$ had comparable HDDs within the experimental time frame considered in this study.

\subsubsection{Effect of IS on ENPs aggregation}

The stability of ENPs is known to be influence by IS in aqueous media $[7,30,110]$ such that as the concentration of electrolytes increases $\zeta$-potential decreases with concomitant increase in ENPs aggregation. The effect of IS on the aggregation of $\mathrm{nAl}_{2} \mathrm{O}_{3}$ and $\mathrm{nCuO}$ investigated using monovalent $\mathrm{NaCl}$ ( 1 and $10 \mathrm{mM}$ ) at circumneutral $\mathrm{pH}$ in DIW was observed to be concentration dependent. Lower $\zeta$-potential was observed at higher IS (10 mM) over $48 \mathrm{~h}$ (Fig. 3a, C), and more apparent for the nCuO (Fig. 3c) irrespective of the exposure concentration. At low IS (1 mM), no $\zeta$-potential variations were observed at lower exposure concentrations ( 0.1 and $1 \mathrm{mg} / \mathrm{L}$ ) relative to the control irrespective of ENPs type (Fig. 2a, C) and (Fig. 3a, C).

Polydispersity index (PDI) ranged from 0.4 to 1 for both ENPs; with effect of IS being higher on $\mathrm{nAl}_{2} \mathrm{O}_{3}$ as evidenced by larger HDD size distribution shown in Fig. $3 \mathrm{~b}$. The observed change in $\zeta$-potential, however, as IS was increased from 1 to $10 \mathrm{mM}$ had no considerable effect on HDD (Fig. 3b, d) except for $\mathrm{nAl}_{2} \mathrm{O}_{3}$ after $24 \mathrm{~h}$ (Fig. 3b) 


\section{$\bullet 0.1 \mathrm{mg} / \mathrm{L} \quad \Delta 1 \mathrm{mg} / \mathrm{L} \quad \square 10 \mathrm{mg} / \mathrm{L} \quad(1 \mathrm{mM} \mathrm{NaCl})$ \\ $\bigcirc 0.1 \mathrm{mg} / \mathrm{L} \quad \Delta 1 \mathrm{mg} / \mathrm{L} \quad \square 10 \mathrm{mg} / \mathrm{L} \quad(10 \mathrm{mM} \mathrm{NaCl})$}
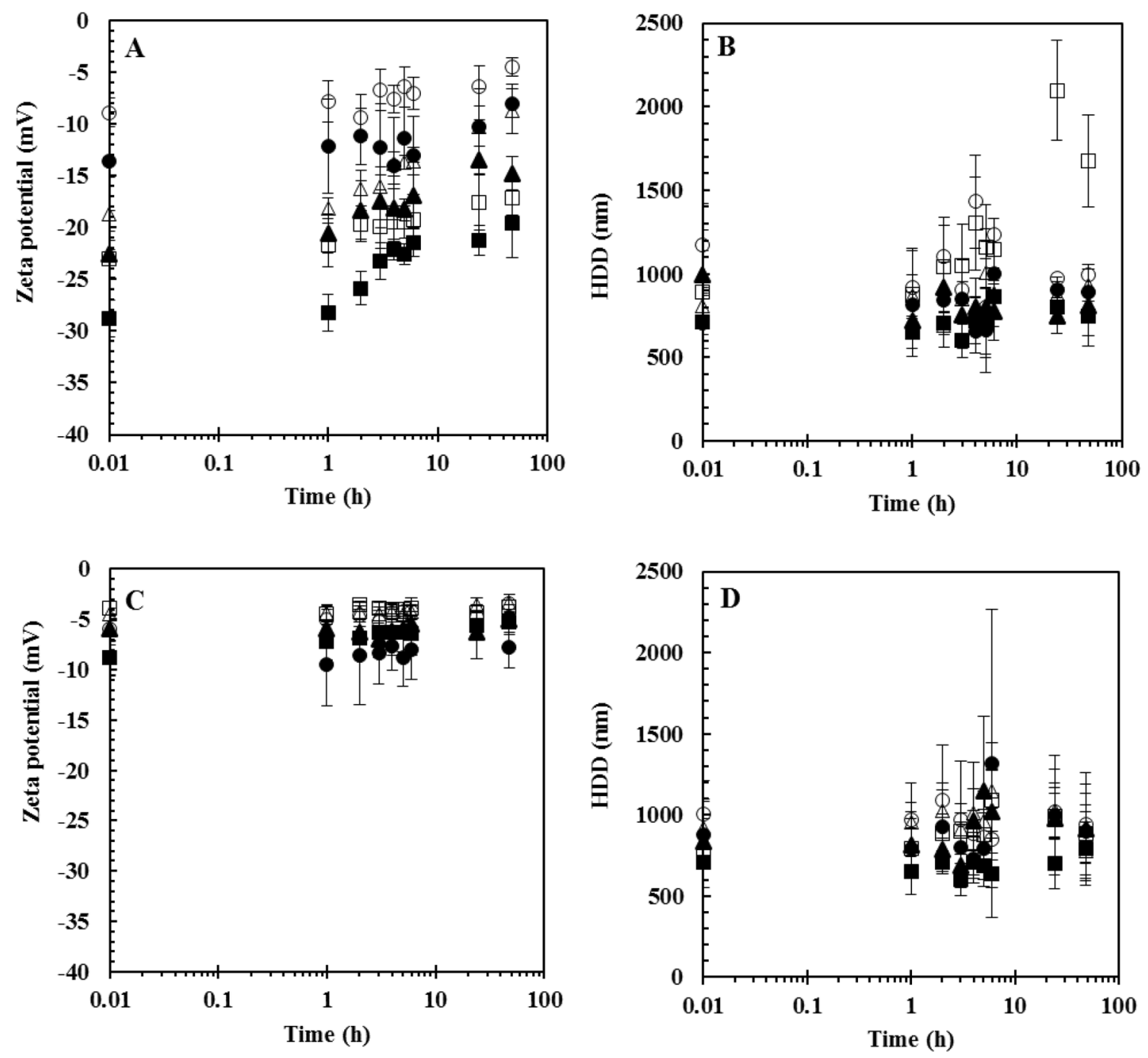

Fig. 3 -potential and $\mathrm{HDD}$ for $\mathrm{nAl}_{2} \mathrm{O}_{3}(\mathbf{a}$ and $\mathbf{b}$ ), respectively), and $\mathrm{nCuO}$ (c and d), respectively) in DIW at 1 and $10 \mathrm{mM} \mathrm{NaCl}(\mathrm{pH} 7)$ over $48 \mathrm{~h}$

at $10 \mathrm{mg} / \mathrm{L}$. Results of Godymchuk et al. [33], however, reported significant influence of IS on $\zeta$-potential and HDD where very high concentrations of up to $100 \mathrm{mM} \mathrm{NaCl}$ at circumneutral $\mathrm{pH}$ for $\mathrm{nAl}_{2} \mathrm{O}_{3}$ were used. Herein, critical coagulation concentration (CCC) was not determined but is known to vary with ENPs specific properties and exposure media chemistry attributes. For example, $\mathrm{CCC}$ of $\mathrm{NaCl}$ on $\mathrm{nCuO}$ was reported as $40 \mathrm{mM}$ and $75 \mathrm{mM}$, respectively, in the absence and presence of Suwannee river NOM [2] but in $\mathrm{NaNO}_{3}$ on bare $\mathrm{nCuO}$ under wastewater environment a CCC value of $54.2 \mathrm{mM}$ was observed [69].

Results show no considerable change in $\zeta$-potential ( $<5 \mathrm{mV}$ as IS increased from 1 to $10 \mathrm{mM}$ for $\mathrm{nCuO}$ ); irrespective of exposure concentration because $\mathrm{Na}^{+}$exerts weak influence on aggregation (Fig. 3c). In previous studies where significant $\zeta$-potential reduction, and corresponding increase in $\mathrm{HDD}$ were observed for $\mathrm{nCuO}$, both very high exposure ENPs concentrations (e.g. $>100 \mathrm{mg} / \mathrm{L}$ ) and IS were used (up to $100 \mathrm{mM}$ ). Peng et al. [87], for example, used up to $100 \mathrm{mM} \mathrm{NaCl}$ on $100 \mathrm{mg} / \mathrm{L} \mathrm{nCuO}$. Consequently, a decline in $\zeta$-potential, and high HDD were observed.

Remarkably, in this study, low concentrations of electrolytes (representing IS) were used similar to those widely found in the natural environment [37, 45]. In freshwater systems, $\mathrm{Na}^{+}$concentrations ranges from 0.26 to $0.78 \mathrm{mM}[37,45]$, and much lower for $\mathrm{K}^{+}$ (0.001 to $0.005 \mathrm{mM}$ ) [101]. Hence, results show that at 
low concentrations of monovalent electrolytes widely found in actual environmental systems are inadequate to screen the electrostatic repulsion where the electrical double-layer [58] shrinks, and consequently, promote aggregation [126]. Findings of Khan et al. [51], showed that at low IS due to monovalent electrolyte $\mathrm{NaCl}$ induced limited aggregation, and sedimentation efficiency to $\mathrm{nZnO}$. Overall, monovalent electrolytes such as $\mathrm{Na}^{+}$are likely to induce marginal or no change in aggregation of metal oxide-based ENPs as attested by the results of $\mathrm{nAl}_{2} \mathrm{O}_{3}$ and $\mathrm{nCuO}$ in Figs. $3 \mathrm{~b}$ and $d$, respectively.

$0.1 \mathrm{mg} / \mathrm{L}$

$\Delta 1 \mathrm{mg} / \mathrm{L}$

$0.1 \mathrm{mg} / \mathrm{L}$

$\triangle \mathbf{1 ~ m g / L}$
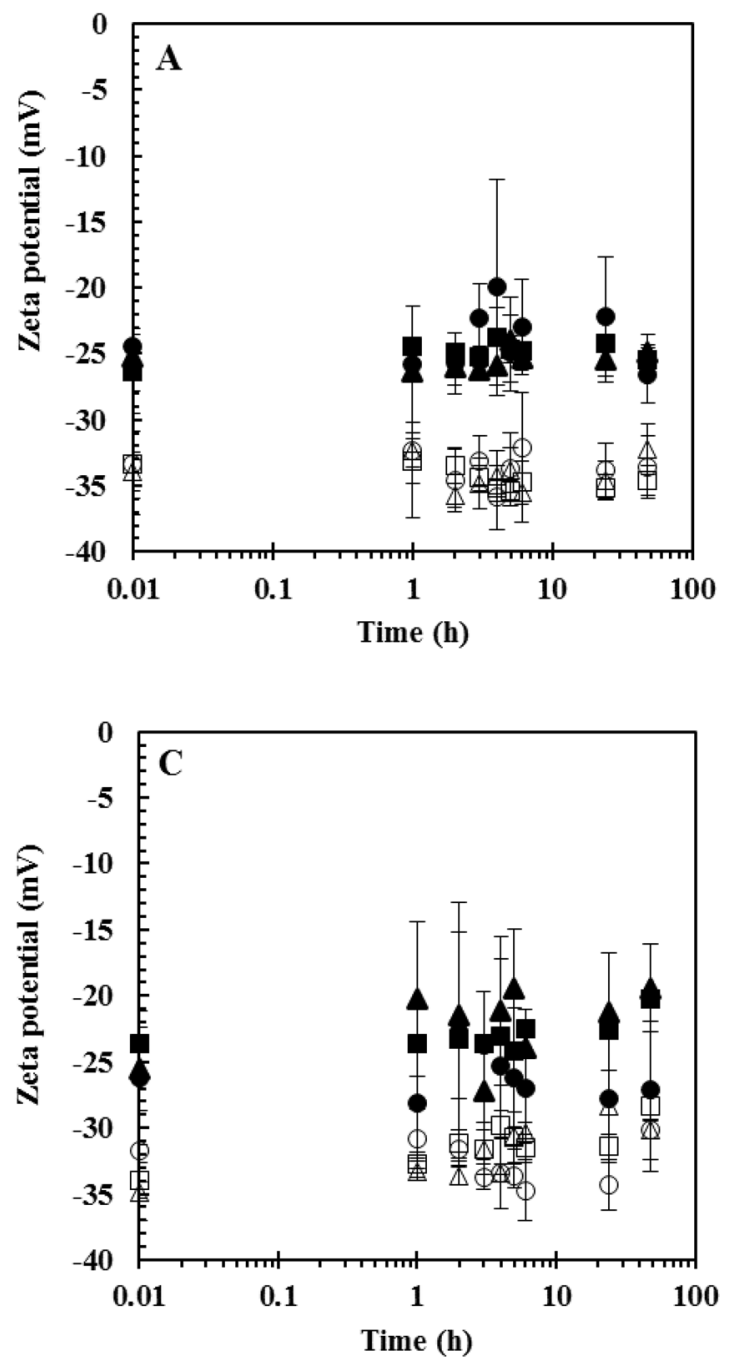

\subsubsection{Influence of HA on ENPs aggregation}

Numerous studies have shown that NOM play an important role on the aggregation of ENPs $[5,11,66,80,84]$, and natural colloids [115] in aqueous media. This is because NOMs are negatively charged [81] linked to the presence of numerous carboxyl and phenolic groups, and therefore, provides stabilization through steric repulsion and/or electrostatic forces [89]. Herein, HA was used as surrogate for NOM. Results on $\zeta$-potential and aggregation (Fig. 4) show that as the concentration of HA increased, $\zeta$-potentials of the ENPs increased (higher negative charge) and the effect was concentration dependent (Figs. 4a and 4c).
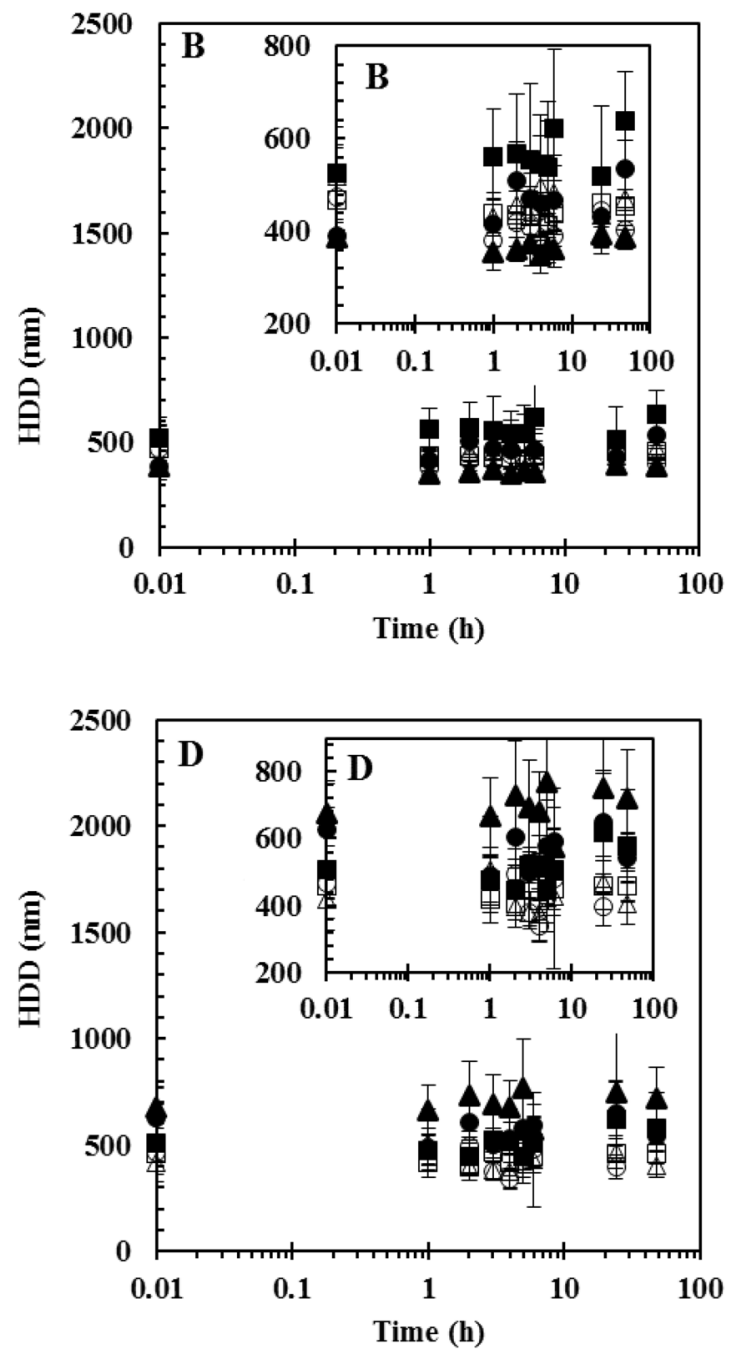

Fig. 4 -potential and $\mathrm{HDD}$ for $\mathrm{nAl}_{2} \mathrm{O}_{3}$ (a and $\mathbf{b}$, respectively), and $\mathrm{nCuO}$ (c and d, respectively) in DIW at 1 and $10 \mathrm{mg} / \mathrm{L} \mathrm{HA}$ (pH 7) over $48 \mathrm{~h}$ 
For example, ENPs surfaces are known to be modified by $\mathrm{HA}$, and due to increased repulsive energy results in inhibition of aggregation [24, 102, 118, 125]. Herein, in absence of NOM $(0 \mathrm{mg} / \mathrm{L})$ at circumneutral $\mathrm{pH}$, and lowest concentration of ENPs $(0.1 \mathrm{mg} / \mathrm{L})$, negative $\zeta$-potentials of $<-24$ (Fig. 2a) and $<-10 \mathrm{mV}$ (insert in Fig. 2c) were observed for $\mathrm{nAl}_{2} \mathrm{O}_{3}$ and $\mathrm{nCuO}$, respectively. However, at $10 \mathrm{mg} / \mathrm{L} \mathrm{NOM}, \zeta$-potentials of $<-25 \mathrm{mV}$ were apparent as shown in Fig. $4 \mathrm{a}\left(\mathrm{nAl}_{2} \mathrm{O}_{3}\right)$ and $4 \mathrm{c}(\mathrm{nCuO})$, and with corresponding lower sized-aggregates $(<700 \mathrm{~nm}$ (Fig. 4b), and $<800 \mathrm{~nm}$ (Fig. 4d). In addition, even after $48 \mathrm{~h}$, limited change in HDD was apparent for both ENPs (Figs. 4b, d) as HA-coated ENPs were observed to be well dispersed, in suspension, and stable compared to ENPs in the control (Figs. 2b, d). Therefore, results herein offer antecedent evidence of adsorption of $\mathrm{HA}$ (although adsorption was not done) onto ENPs where HA enhanced steric and/or electrostatic repulsion; thus, leading to increased stability.

The increase in negative charge on $\mathrm{nAl}_{2} \mathrm{O}_{3}$ and $\mathrm{nCuO}$ surfaces at $\mathrm{pH} 7$ was plausibly due to the adsorption of $\mathrm{HA}$ - a process highly controlled by electrostatic interaction, and specific adsorption through ligand exchange [118]. The lower Z-potential, however, observed on nCuO in the presence of $\mathrm{HA}$ possibly can be accounted by threefold processes. First, the larger surface area of $\mathrm{nAl}_{2} \mathrm{O}_{3}$ $\left(50.5 \mathrm{~m}^{2} / \mathrm{g}\right)$ compared to that of $\mathrm{nCuO}\left(1.85 \mathrm{~m}^{2} / \mathrm{g}\right)$ may have enhanced higher adsorption of $\mathrm{HA}$ on the former. This is because ENPs with larger surface area exhibit higher adsorption capacity for $\mathrm{NOM}$ [71]. For instance, $\mathrm{nFe}_{2} \mathrm{O}_{3}$ was shown to adsorb more NOM than $\mathrm{nTiO}_{2}$ as it had larger surface area, irrespective of exposure media (e.g. groundwater, lake water, etc.) [17]. Secondly, ligand exchange between $\mathrm{HA}$ and metal oxide ENPs could have occurred [118], for example, the hydroxyl groups on metal oxide surfaces with NOM may have provided fewer hydroxyl groups for protonation which may partly account for the lower measured $\zeta$-potential of $\mathrm{nCuO}$, as a similar case has been reported for $\mathrm{nZnO}$ [11].

Finally, organic anions in HA may have increased the negative charge density adjacent to the particle surface; thus causing a shift in the position of the shear plane away from the surface leading to a decrease in $\zeta$-potential [11, 125] — where this phenomenon was likely more apparent on $\mathrm{nCuO}$. Previously, it has been observed that at low concentration (in this case $1 \mathrm{mg} / \mathrm{L}$ ), HA promote electrostatic stabilization. However, at higher concentrations both steric and electrostatic stabilization processes promote the stability of ENPs (10 mg/L) [18]. This may account for lower HDD at higher HA concentration of $10 \mathrm{mg} / \mathrm{L}$ as summarized in Figs. $4 b$, d. Due to the complexity of interactions between ENPs and $\mathrm{HA}$, plausibly the three processes were more likely to have occurred concurrently which accounts for the differences in the aggregation of $\mathrm{nAl}_{2} \mathrm{O}_{3}$ and $\mathrm{nCuO}$ in the presence of $\mathrm{HA}$.

\subsection{Aggregation kinetics of ENPs in river water}

Aggregation in river water was observed to be concentration dependent with $10 \mathrm{mg} / \mathrm{L}$ of ENPs having the highest $\mathrm{HDD}$, and least at $0.1 \mathrm{mg} / \mathrm{L}$ as summarised in Figs. 5 and 6 for $\mathrm{nAl}_{2} \mathrm{O}_{3}$ and $\mathrm{nCuO}$, respectively. At higher exposure concentrations of ENPs ( 1 and 10$) \mathrm{mg} / \mathrm{L}$, immediate aggregation in the river water especially during the first $6 \mathrm{~h}$ except for $\mathrm{nAl}_{2} \mathrm{O}_{3}$ in $\mathrm{BR}$ was observed, although the difference was marginal, raise the possibility of ENPs concurrent residence between the water, and sediment columns. The reason being $\mathrm{nAl}_{2} \mathrm{O}_{3}$ had higher surface area which could have enhanced rapid adsorption of NOM, thus reducing the likely higher aggregation as opposed to the case of $\mathrm{nCuO}$. At $0.1 \mathrm{mg} / \mathrm{L}$, for both ENPs, HDD remained stable $<350 \mathrm{~nm}$ over $48 \mathrm{~h}$ (Figs. 5b, d, and 6b, d). The high concentrations of DOC (surrogate for NOM) (Table 1) in river water can adsorb onto the particle surfaces, and hence, form a barrier that inhibits aggregation leading to highly stable ENPs.

HDD $(<700 \mathrm{~nm})$ for both ENPs (Figs. 5b, d, and 6b, d) had no considerable change over $48 \mathrm{~h}$. This implies their likely longer residence in the aqueous media, and in turn, may interact with aquatic organisms in the water column. High concentrations of electrolytes (monovalent and divalent cations in Table 1) had IS of $5.35 \mathrm{mM}$ and $2.48 \mathrm{mM}$ in $B R$ and $E R$, respectively, but showed no considerable influence on aggregation irrespective of ENPs type (Figs. 5d, 6d). The reason being although BR had higher IS $(5.35 \mathrm{mM})$ this was countered by high NOM concentration ( $8.25 \mathrm{mg} / \mathrm{L})$, and ER had low IS ( $2.48 \mathrm{mM})$; thus, the stabilization effects of NOM on ENPs were dominant. Our results are in agreement with similar observations reported in the literature in natural water $[40,93]$ even in cases where IS was high. For example, possible strong coagulation due to high concentration of divalent ions (e.g. $\mathrm{Ca}^{2+}$ and $\mathrm{Mg}^{2+}$ ) were likely inhibited by NOM in river water. As such, dispersions of ENPs may dynamically be either in water column or sediment, and therefore, under such scenarios, aquatic organisms within the water column (e.g. filter-feeders like Daphnia magna, and certain classes of fish) as well as benthic filter-feeding invertebrates may concurrently be exposed to ENPs over extended period as earlier reported by Liu et al. [62] under freshwater conditions.

After $48 \mathrm{~h}$, ENPs formed larger aggregates at $10 \mathrm{mg} / \mathrm{L}$ an indication that at higher exposure concentrations they will most likely through sedimentation process settle on the sediments. Results in Table 1 show both river waters had NOM concentrations within those reported in freshwater $(0.5$ to $10 \mathrm{mg} / \mathrm{L})$ [81]. Studies have reported that the adsorption of different components of NOM onto 
$\bullet 0.1 \mathrm{mg} / \mathrm{L} \quad \Delta 1 \mathrm{mg} / \mathrm{L} \quad \square 10 \mathrm{mg} / \mathrm{L}$
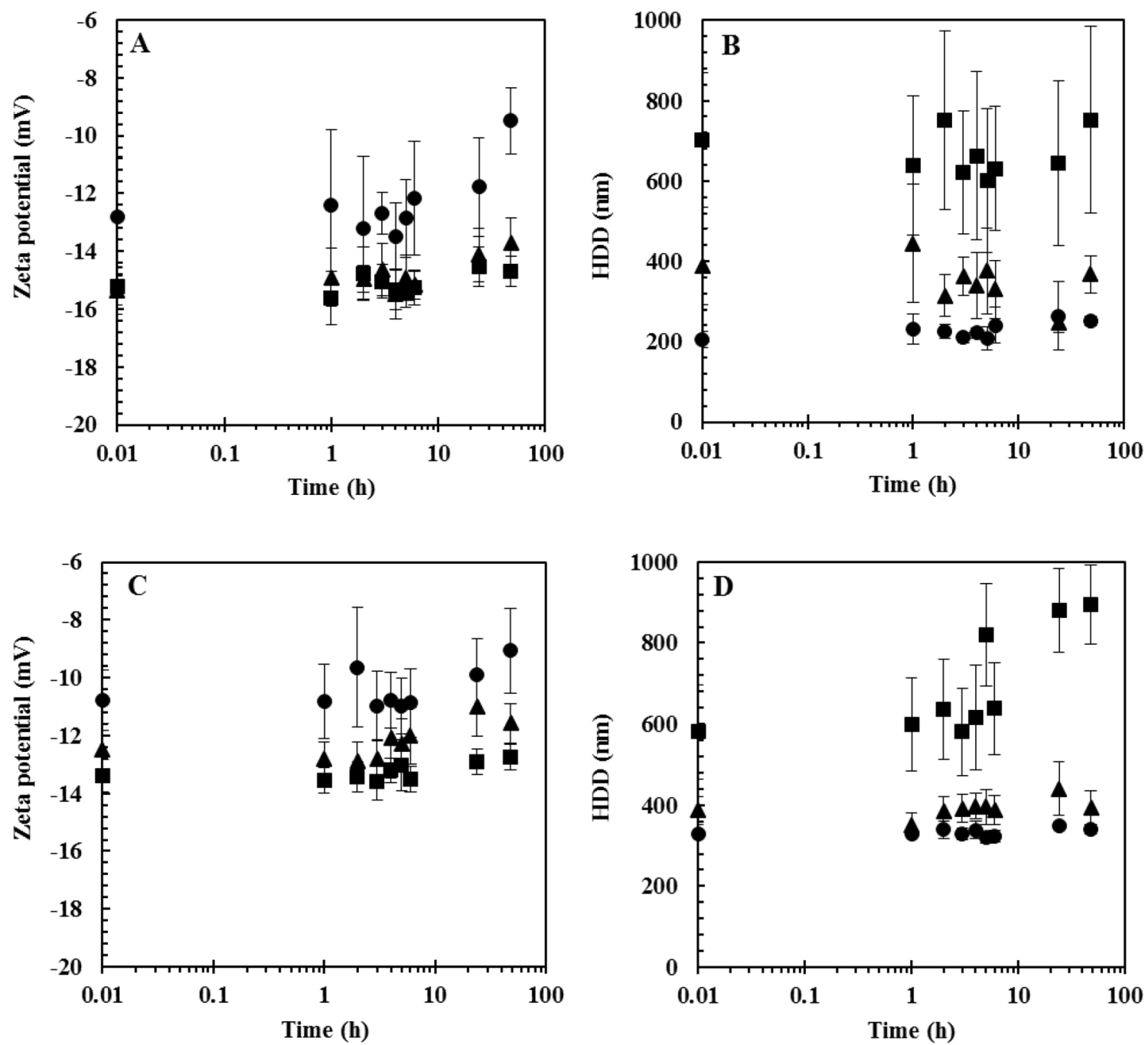

Fig. 5 ל-potential and $\mathrm{HDD}$ ( $\mathbf{a}$ and $\mathbf{b}$, respectively) in $\mathrm{ER}$, and (c and $\mathbf{d}$, respectively) in $\mathrm{BR}$ for $\mathrm{nAl}_{2} \mathrm{O}_{3}$ over $48 \mathrm{~h}$

ENPs surfaces is dependent on NOM type (linked to their molecular weight and chemical functionality) - with higher adsorption affinity apparent in NOMs with higher molecular weight $[16,78,124]$. Hence, although in this study the distribution of different NOM components (HA, $\mathrm{FA}$, etc.) in each river water were not determined; but may partially account for the observed differences in aggregation of the ENPs linked to differences in molecular weight.

Current and expected future concentrations of ENPs in freshwater systems are several orders of magnitude lower than $0.1 \mathrm{mg} / \mathrm{L}$ used in this study based on modelled [13, $34,49,76]$ and detected concentrations $[27,47,87,120]$. Therefore, findings herein show that ENPs may be stable in natural water systems. This implies the stabilized ENPs can interact with water-column or sediment dwelling organisms, and as a result possibly induce deleterious toxic effects to aquatic life.

\subsection{Dissolution studies of ENPs in river water}

Dissolution studies over $48 \mathrm{~h}$ aided to gain insights on temporal effect in terms of ionic or particulates, or both forms for $\mathrm{nAl}_{2} \mathrm{O}_{3}$ and $\mathrm{nCuO}$ in natural water matrixes. No particulates were detected in all the filtered samples. Results show that dissolution was time dependent at a given exposure concentration ( 0.1 or $1 \mathrm{mg} / \mathrm{L}$ ) as shown in Table 2. Dissolution studies at exposure concentration of $10 \mathrm{mg} / \mathrm{L} \mathrm{ENPs}$ was not done. This is because it was considered too high to be environmentally relevant in river water systems. 
$\bullet 0.1 \mathrm{mg} / \mathrm{L} \quad \Delta 1 \mathrm{mg} / \mathrm{L} \quad \square 10 \mathrm{mg} / \mathrm{L}$
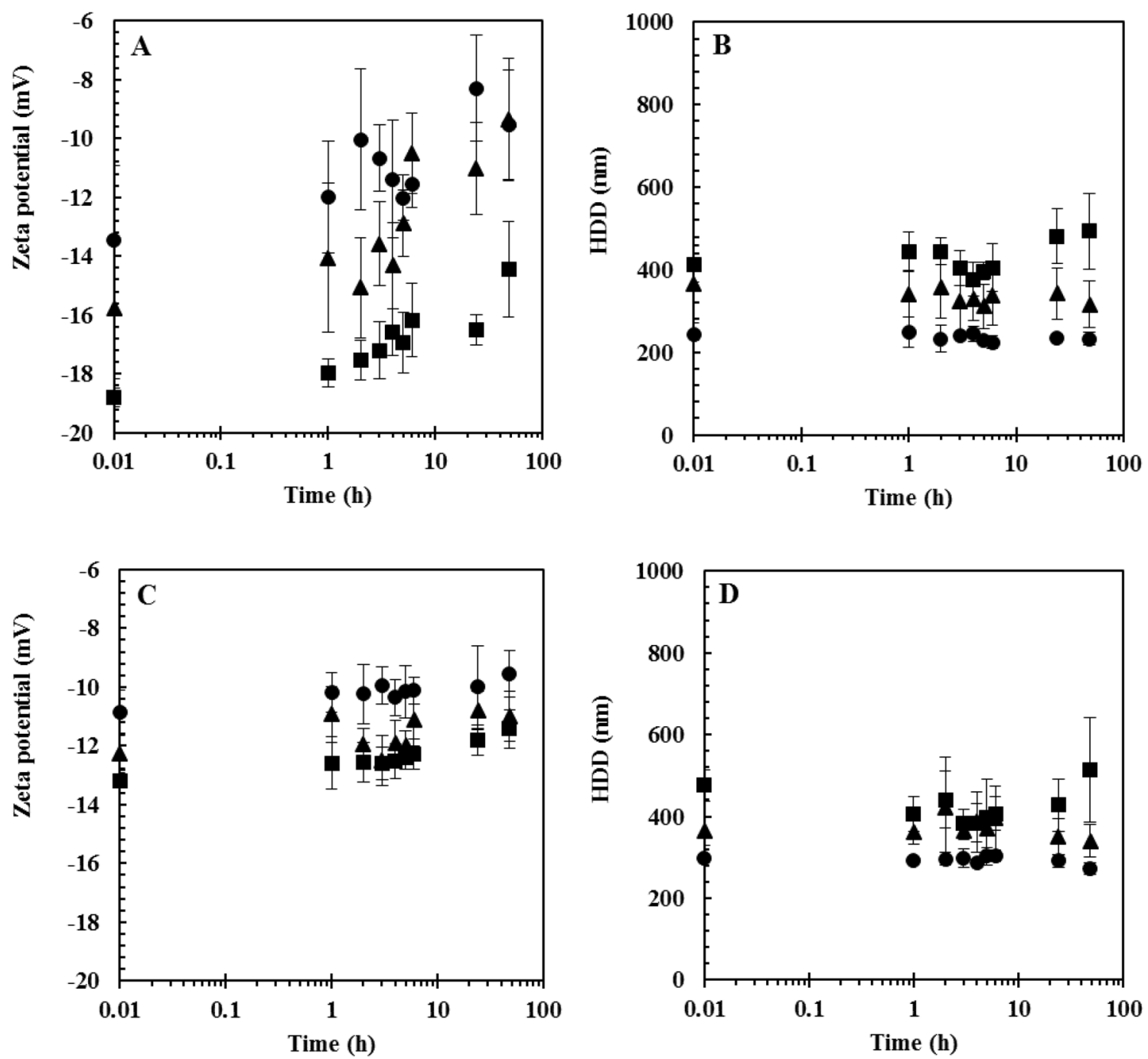

Fig. 6 -potential and HDD (a and b, respectively) in ER, and (c and d, respectively) in BR for $\mathrm{nCuO}$ over $48 \mathrm{~h}$

Table 2 Dissolution of ENPs in natural river water samples used in this study done in triplicates using ICP-MS

\begin{tabular}{|c|c|c|c|c|}
\hline \multirow[t]{2}{*}{ River/NC* } & \multicolumn{2}{|l|}{$\mathrm{Cu}^{2+}(\mu \mathrm{g} / \mathrm{L})$} & \multicolumn{2}{|l|}{$A l^{3+}(\mu \mathrm{g} / \mathrm{L})$} \\
\hline & $0.1 \mathrm{mg} / \mathrm{L}$ & $1 \mathrm{mg} / \mathrm{L}$ & $0.1 \mathrm{mg} / \mathrm{L}$ & $1 \mathrm{mg} / \mathrm{L}$ \\
\hline $\mathrm{BR}(2 \mathrm{~h})$ & $4.07 \pm 1.05$ & $6.39 \pm 0.60$ & $4.36 \pm 1.76$ & $17.90 \pm 1.21$ \\
\hline $\mathrm{BR}(48 \mathrm{~h})$ & $4.75 \pm 1.32$ & $8.97 \pm 1.41$ & $8.27 \pm 1.02$ & $38.23 \pm 1.92$ \\
\hline $\mathrm{ER}(2 \mathrm{~h})$ & $2.84 \pm 0.71$ & $6.40 \pm 1.54$ & $14.87 \pm 1.25$ & $153.43 \pm 8.56$ \\
\hline $\mathrm{ER}(48 \mathrm{~h})$ & $3.13 \pm 0.38$ & $11.53 \pm 2.41$ & $22.29 \pm 1.60$ & $162.13 \pm 7.87$ \\
\hline
\end{tabular}

${ }^{*} N C$ nominal concentration

The dissolution of $\mathrm{nCuO}$ was $0.8 \%$ at $2 \mathrm{~h}$ and increased to $1.44 \%$ after $48 \mathrm{~h}$ in ER water samples at nominal exposure concentration of $1 \mathrm{mg} / \mathrm{L}$ (Table 2). However, in BR water samples, the presence of high NOM (Table 1) may have adsorbed the $\mathrm{Cu}^{2+}$ resulting in lower detected concentrations over $48 \mathrm{~h}$. Previously, NOM was found to significantly enhance dissolution of ENPs $[46,63,117]$ through ligand-promoted dissolution [72]. However, NOM can also impede dissolution by adsorbing onto the active sites of ENPs $[25,124]$. This is via various functional groups present on NOM e.g. carboxylic and phenolic groups that can form complexes with released ions with resultant reduction in the amount of detectable ions [19]. For example, Conway et al. [20] investigated the dissolution of $1 \mathrm{mg} / \mathrm{L} \mathrm{nCuO} \mathrm{in}$ wastewater and storm run water with NOM concentrations of 2.38 and $6.49 \mathrm{mg} / \mathrm{L}$ with dissolution being $<10 \%$ and $0 \%$, respectively. Miao et al. [69] also observed $<5 \%$ dissolution of $\mathrm{nCuO}$ in wastewater. In addition, present 
in natural water matrixes are complex-forming anions (e.g. $\mathrm{Cl}^{-1}, \mathrm{SO}_{4}{ }^{2-}, \mathrm{PO}_{4}{ }^{3-}$, etc.) as listed in Table 1. Hence, the released $\mathrm{Cu}^{2+}$ may have also formed precipitation complexes such as $\mathrm{Cu}_{3}\left(\mathrm{PO}_{4}\right)_{2}, \mathrm{CuCl}$ or $\mathrm{CuS}$, thus reducing the detectable free ions.

Moreover, copper can precipitate as hydroxide in $\mathrm{pH}$ range of 6.6 to 7.8 with ligands present in freshwater [26] - a pH value close to that of freshwater matrixes used in this study. Dissolution of $\mathrm{nCuO}$ at $1 \mathrm{mg} / \mathrm{L}$ was observed to decrease with increasing $\mathrm{pH}$ where at $\mathrm{pH}>7.7$ very low dissolution was observed (<3\%) [82]. In addition, nCuO is known to have limited dissolution in natural waters in the $\mathrm{pH}$ range of 8.0-8.3 [40]. Therefore, low dissolution reported herein agrees with the literature (river water samples had pH of 7.9 and 8.1 (Table 1)). Low dissolution of $\mathrm{nCuO}$ in freshwater systems implies that resultant toxicity to aquatic life in freshwater may be predominantly linked to the particulate forms.

Dissolution of $\mathrm{nAl}_{2} \mathrm{O}_{3}$ at nominal exposure concentration of $1 \mathrm{mg} / \mathrm{L}$ was high in ER water compared to $\mathrm{BR}$, and time effect was apparent in BR water (an increase of over $100 \%$ ) but not in ER water (Table 2). In ER water, for example, after $2 \mathrm{~h}$ the dissolution increased from 29 to $30.6 \%$ after $48 \mathrm{~h}$ whereas in $\mathrm{BR}$, dissolution was $\leq 8 \%$ even after $48 \mathrm{~h}$ (Table 2). Results of dissolution for $\mathrm{nAl}_{2} \mathrm{O}_{3}$ at $1 \mathrm{mg} / \mathrm{L}$ after $48 \mathrm{~h}$ in this study (30.6 and $8 \%$ for $E R$ and $B R$, respectively) were much lower compared to findings of Pakrashi et al. [86] in lake water ( 94\% dissolution). However, at $0.1 \mathrm{mg} / \mathrm{L}$, after $48 \mathrm{~h}$, higher dissolution was observed in ER and $B R$ water samples as 42.1 and $15.6 \%$, respectively. For $\mathrm{nAl}_{2} \mathrm{O}_{3}$, the difference in dissolution of between $\mathrm{ER}$ and $\mathrm{BR}$ water samples were attributed to water chemistry driven factors e.g. NOM linked to differences in molecular weight and chemical functionality. For example, in BR the NOMtype may have promoted higher adsorption onto ENPs leading to formation of a coating that in turn impeded dissolution $[32,86]$. Results of high dissolution at $0.1 \mathrm{mg} / \mathrm{L}$ in ER water samples corresponded to low HDD observed $(\leq 250 \mathrm{~nm}$ ) (Fig. 5 b) compared to results in BR water where aggregates of $>300 \mathrm{~nm}$ were observed (Fig. $5 \mathrm{~d}$ ). The high dissolution of $\mathrm{nAl}_{2} \mathrm{O}_{3}$ in freshwater systems (especially at low concentrations $\leq 0.1 \mathrm{mg} / \mathrm{L}$ ) as observed in this study implies its likely toxicity may be attributed to both ionic and particulate species $[10,85,94]$.

Overall, there are increasing efforts to elucidate the fate of ENPs in natural water matrixes (e.g. river water, lake water, sea water, etc.) $[20,40,96,119]$, however, the reported cases are too few to aid draw firm conclusions hence study findings herein contribute in filling part of current data gaps. Most data in the published literature suggest that both particulates and ionic species may account for the observed adverse effects of ENPs to aquatic organisms. However, this aspect cannot be generalized since water chemistry play a key role in determining the fate of ENPs in aquatic systems as shown herein. One key limitation in published studies is lack of reporting physical-chemical properties of the natural water exposure media. For example, the marked differences in $\mathrm{nAl}_{2} \mathrm{O}_{3}$ dissolution observed herein and data reported by Pakrashi et al. [86] could not be accounted for linked to lack of exposure media attributes in the later study. Thus, such data is essential as realistic estimates of ENPs fate in environmentally relevant conditions continue to increase. This is unlike the case of Heinlaan et al. [40] where results of $\mathrm{nCuO}$ could be compared to current study since in both cases the exposure media parameters were reported.

\section{Conclusions}

Aggregation and dissolution of ENPs in aquatic systems is influenced principally by $\mathrm{pH}$, IS and NOM. The $\mathrm{pH}$ determines the $\zeta$-potential of ENPs which in turn influences their aggregation. Maximum aggregation is observed at $\mathrm{pH}_{\mathrm{IEP}}$. IS due to presence of electrolytes in aqueous systems of ENPs compresses the electric double layer leading to a reduction in $\zeta$-potential. At lower concentrations of ENPs, the reduction in $\zeta$-potential has no considerable effect on HDD. The adsorption of NOM onto the surfaces of ENPs results in an increase in $\zeta$-potential. The adsorption capacity of NOM by ENPs depends on their surface area. Larger surface area implies high adsorption capacity leading to greater increase in $\zeta$-potential, impeding aggregation. In freshwater systems with extremely complex composition, the aggregation and dissolution of ENPs is not determined by a single factor. This is because of the combined factors counteracting each other to yield the observed effects.

In freshwater systems, ENPs are stable with $\zeta$-potential and HDD varying slightly at different concentrations of ENPs. The dissolution of ENPs is influenced by NOM which provides a surface coating and it is higher at lower than at higher concentration. In freshwater systems, ENPs exist as either aggregates or release ions. Therefore, organisms are not exposed to pristine ENPs but rather to transformed forms. The released ions undergo speciation via chelation and precipitation among other processes. As a result, the released ions might not be available to pose the toxicity predicted by studies conducted in DIW. The current study suggests that ENPs are more stable in freshwater than in DIW. The high stability of ENPs in freshwater implies their likelihood to interact with aquatic organisms in ways not necessarily predicted by extrapolation from experimental results based on DIW. The findings herein show the unique influence of source-specific water chemistry on aggregation and dissolution of ENPs at close to environmentally 
relevant concentrations. Hence, it is impossible to generalise the fate and transformation of ENPs in aquatic systems.

Acknowledgements This study was supported by the Water Research Commission of South Africa (K5/2509/1), and the University of Pretoria (AOY229). The authors would like to thank the Laboratory for Microscopy and Microanalysis at University of Pretoria for assistance with microscopy sample analysis, and the Botswana International University of Science and Technology (BIUST) for PXRD analysis.

Author contributions All the authors contributed to this work. AFN and NM planned the experiments and all experiments were performed by AFN. Experimental data processing and analysis was performed and discussed by AFN, NM and WWF. All the authors read, commented on, and approved the final version of the manuscript.

\section{Compliance with ethical standards}

Conflict of interest The authors declare no competing interests.

\section{References}

1. Abdel-Khalek AA, Kadry MA, Badran SR, M-aS M (2015) Comparative toxicity of copper oxide bulk and nano particles in Nile tilapia; Oreochromis niloticus: biochemical and oxidative stress. J Basic Appl Zool 72:43-57

2. Adeleye AS, Conway JR, Perez T, Rutten P, Keller AA (2014) Influence of extracellular polymeric substances on the long-term fate, dissolution, and speciation of copper-based nanoparticles. Environ Sci Technol 48:12561-12568

3. Amde M, Liu J-F, Tan Z-Q, Bekana D (2017) Transformation and bioavailability of metal oxide nanoparticles in aquatic and terrestrial environments. A review. Environ Pollut 230:250-267

4. Applerot G, Lellouche J, Lipovsky A, Nitzan Y, Lubart R, Gedanken A, Banin E (2012) Understanding the antibacterial mechanism of $\mathrm{CuO}$ nanoparticles: revealing the route of induced oxidative stress. Small 8:3326-3337

5. Baalousha $M$ (2009) Aggregation and disaggregation of iron oxide nanoparticles: influence of particle concentration, $\mathrm{pH}$ and natural organic matter. Sci Total Environ 407:2093-2101

6. Baalousha M, Manciulea A, Cumberland S, Kendall K, Lead JR (2008) Aggregation and surface properties of iron oxide nanoparticles: influence of $\mathrm{pH}$ and natural organic matter. Environ Toxicol Chem 27:1875-1882

7. Badawy AME, Luxton TP, Silva RG, Scheckel KG, Suidan MT, Tolaymat TM (2010) Impact of environmental conditions $(\mathrm{pH}$, ionic strength, and electrolyte type) on the surface charge and aggregation of silver nanoparticles suspensions. Environ Sci Technol 44:1260-1266

8. Bäuerlein PS, Emke E, Tromp P, Hofman JA, Carboni A, Schooneman F, De Voogt P, Van Wezel AP (2017) Is there evidence for man-made nanoparticles in the Dutch environment? Sci Total Environ 576:273-283

9. Benavides $M$, Fernández-Lodeiro J, Coelho $P$, Lodeiro $C$, Diniz MS (2016) Single and combined effects of aluminum $\left(\mathrm{Al}_{2} \mathrm{O}_{3}\right)$ and zinc ( $\mathrm{ZnO})$ oxide nanoparticles in a freshwater fish, Carassius auratus. Environ Sci Pollut Res 23:24578-24591

10. Bhuvaneshwari $M$, Bairoliya $S$, Parashar $A$, Chandrasekaran $N$, Mukherjee $\mathrm{A}$ (2016) Differential toxicity of $\mathrm{Al}_{2} \mathrm{O}_{3}$ particles on Gram-positive and Gram-negative sediment bacterial isolates from freshwater. Environ Sci Pollu Res 23:12095-12106
11. Bian S-W, Mudunkotuwa IA, Rupasinghe T, Grassian VH (2011) Aggregation and dissolution of $4 \mathrm{~nm} \mathrm{ZnO}$ nanoparticles in aqueous environments: influence of $\mathrm{pH}$, ionic strength, size, and adsorption of humic acid. Langmuir 27:6059-6068

12. Bondarenko O, Juganson $K$, Ivask A, Kasemets K, Mortimer M, Kahru A (2013) Toxicity of Ag, CuO and ZnO nanoparticles to selected environmentally relevant test organisms and mammalian cells in vitro: a critical review. Arch Toxicol $87: 1181-1200$

13. Boxall $A B, C$ haudhry $Q$, Sinclair $C$, Jones $A$, Aitken $R$, Jefferson $B$, Watts $C$ (2007) Current and future predicted environmental exposure to engineered nanoparticles. Central Science Laboratory, Department of the Environment and Rural Affairs, London, p 89

14. Carlson CA (2002) Production and removal processes. Biogeochem Mar Dissolv Organ Matt 91-151

15. Chaúque E, Zvimba J, Ngila J, Musee N (2016) Fate, behaviour, and implications of $\mathrm{ZnO}$ nanoparticles in a simulated wastewater treatment plant. Water SA 42:72-81

16. Chekli L, Phuntsho S, Roy M, Shon HK (2013) Characterisation of Fe-oxide nanoparticles coated with humic acid and Suwannee River natural organic matter. Sci Total Environ 461:19-27

17. Chekli L, Zhao Y, Tijing L, Phuntsho S, Donner E, Lombi E, Gao B, Shon H (2015) Aggregation behaviour of engineered nanoparticles in natural waters: characterising aggregate structure using on-line laser light scattering. J Hazard Mater 284:190-200

18. Chen G, Liu X, Su C (2012) Distinct effects of humic acid on transport and retention of $\mathrm{TiO}_{2}$ rutile nanoparticles in saturated sand columns. Environ Sci Technol 46:7142-7150

19. Collin B, Tsyusko OV, Starnes DL, Unrine JM (2016) Effect of natural organic matter on dissolution and toxicity of sulfidized silver nanoparticles to Caenorhabditis elegans. Environ Sci Nano 3:728-736

20. Conway JR, Adeleye AS, Gardea-Torresdey J, Keller AA (2015) Aggregation, dissolution, and transformation of copper nanoparticles in natural waters. Environ Sci Technol 49:2749-2756

21. Das D, Nath BC, Phukon P, Dolui SK (2013) Synthesis and evaluation of antioxidant and antibacterial behavior of $\mathrm{CuO}$ nanoparticles. Colloids Surf B Biointerfaces 101:430-433

22. Defriend KA, Wiesner MR, Barron AR (2003) Alumina and aluminate ultrafiltration membranes derived from alumina nanoparticles. J Membr Sci 224:11-28

23. Degen A, Kosec M (2000) Effect of pH and impurities on the surface charge of zinc oxide in aqueous solution. J Eur Ceram Soc 20:667-673

24. Delay M, Dolt T, Woellhaf A, Sembritzki R, Frimmel FH (2011) Interactions and stability of silver nanoparticles in the aqueous phase: influence of natural organic matter (NOM) and ionic strength. J Chromatogr A 1218:4206-4212

25. Deonarine A, Lau BL, Aiken GR, Ryan JN, Hsu-Kim H (2011) Effects of humic substances on precipitation and aggregation of zinc sulfide nanoparticles. Environ Sci Technol 45:3217-3223

26. Dimkpa CO, Mclean JE, Britt DW, Anderson AJ (2015) Nano-CuO and interaction with nano-ZnO or soil bacterium provide evidence for the interference of nanoparticles in metal nutrition of plants. Ecotoxicology 24:119-129

27. Donovan AR, Adams CD, Ma Y, Stephan C, Eichholz T, Shi H (2016) Detection of zinc oxide and cerium dioxide nanoparticles during drinking water treatment by rapid single particle ICP-MS methods. Anal Bioanal Chem 408:5137-5145

28. El-Trass A, Elshamy H, El-Mehasseb I, El-Kemary M (2012) CuO nanoparticles: synthesis, characterization, optical properties and interaction with amino acids. Appl Surf Sci 258:2997-3001

29. Fabrega J, Luoma SN, Tyler CR, Galloway TS, Lead JR (2011) Silver nanoparticles: behaviour and effects in the aquatic environment. Envirron Int 37:517-531 
30. French RA, Jacobson AR, Kim B, Isley SL, Penn RL, Baveye PC (2009) Influence of ionic strength, $\mathrm{pH}$, and cation valence on aggregation kinetics of titanium dioxide nanoparticles. Environ Sci Technol 43:1354-1359

31. Garner KL, Keller AA (2014) Emerging patterns for engineered nanomaterials in the environment: a review of fate and toxicity studies. J Nanopart Res 16:2503

32. Ghosh S, Mashayekhi H, Pan B, Bhowmik P, Xing B (2008) Colloidal behavior of aluminum oxide nanoparticles as affected by $\mathrm{pH}$ and natural organic matter. Langmuir 24:12385-12391

33. Godymchuk A, Karepina E, Yunda E, Bozhko I, Lyamina G, Kuznetsov D, Gusev A, Kosova N (2015) Aggregation of manufactured nanoparticles in aqueous solutions of mono-and bivalent electrolytes. J Nanopart Res 17:211

34. Gottschalk F, Sun T, Nowack B (2013) Environmental concentrations of engineered nanomaterials: review of modeling and analytical studies. Environ Pollut 181:287-300

35. Griffitt RJ, Luo J, Gao J, Bonzongo JC, Barber DS (2008) Effects of particle composition and species on toxicity of metallic nanomaterials in aquatic organisms. Environ Toxicol Chem 27:1972-1978

36. Gulicovski JJ, Čerović LS, Milonjić SK (2008) Point of zero charge and isoelectric point of alumina. Mater Manuf Processes 23:615-619

37. Guo L, Hunt BJ, Santschi PH (2001) Ultrafiltration behavior of major ions $\left(\mathrm{Na}, \mathrm{Ca}, \mathrm{Mg}, \mathrm{F}, \mathrm{Cl}\right.$, and $\left.\mathrm{SO}_{4}\right)$ in natural waters. Water Res 35:1500-1508

38. Haiss W, Thanh NT, Aveyard J, Fernig DG (2007) Determination of size and concentration of gold nanoparticles from UV-Vis spectra. Anal Chem 79:4215-4221

39. Heinlaan M, Kahru A, Kasemets K, Arbeille B, Prensier G, Dubourguier H-C (2011) Changes in the Daphnia magna midgut upon ingestion of copper oxide nanoparticles: a transmission electron microscopy study. Water Res 45:179-190

40. Heinlaan M, Muna M, Knöbel M, Kistler D, Odzak N, Kühnel D, Müller J, Gupta GS, Kumar A, Shanker R (2016) Natural water as the test medium for $\mathrm{Ag}$ and $\mathrm{CuO}$ nanoparticle hazard evaluation: an interlaboratory case study. Environ Pollut 216:689-699

41. Holden PA, Gardea-Torresdey JL, Klaessig F, Turco RF, Mortimer M, Hund-Rinke K, Cohen Hubal EA, Avery D, Barceló D, Behra R (2016) Considerations of environmentally relevant test conditions for improved evaluation of ecological hazards of engineered nanomaterials. Environ Sci Technol 50:6124-6145

42. Holden PA, Klaessig F, Turco RF, Priester JH, Rico CM, Avila-Arias H, Mortimer M, Pacpaco K, Gardea-Torresdey JL (2014) Evaluation of exposure concentrations used in assessing manufactured nanomaterial environmental hazards: are they relevant? Environ Sci Technol 48:10541-10551

43. Hotze EM, Phenrat T, Lowry GV (2010) Nanoparticle aggregation: challenges to understanding transport and reactivity in the environment. J Environ Qual 39:1909-1924

44. Ivask A, Juganson K, Bondarenko O, Mortimer M, Aruoja V, Kasemets K, Blinova I, Heinlaan M, Slaveykova V, Kahru A (2014) Mechanisms of toxic action of $\mathrm{Ag}, \mathrm{ZnO}$ and $\mathrm{CuO}$ nanoparticles to selected ecotoxicological test organisms and mammalian cells in vitro: a comparative review. Nanotoxicology 8:57-71

45. Jalali M, Jalali M (2016) Geochemistry and background concentration of major ions in spring waters in a high-mountain area of the Hamedan (Iran). J Geochem Explor 165:49-61

46. Jiang C, Aiken GR, Hsu-Kim H (2015) Effects of natural organic matter properties on the dissolution kinetics of zinc oxide nanoparticles. Environ Sci Technol 49:11476-11484

47. Johnson AC, Bowes MJ, Crossley A, Jarvie HP, Jurkschat $K$, Jürgens MD, Lawlor AJ, Park B, Rowland P, Spurgeon D (2011) An assessment of the fate, behaviour and environmental risk associated with sunscreen $\mathrm{TiO}_{2}$ nanoparticles in UK field scenarios. Sci Total Environ 409:2503-2510

48. Kaegi R, Voegelin A, Sinnet B, Zuleeg S, Hagendorfer H, Burkhardt M, Siegrist H (2011) Behavior of metallic silver nanoparticles in a pilot wastewater treatment plant. Environ Sci Technol 45:3902-3908

49. Keller AA, Lazareva A (2013) Predicted releases of engineered nanomaterials: from global to regional to local. Environ Sci Technol Lett 1:65-70

50. Kershner RJ, Bullard JW, Cima MJ (2004) Zeta potential orientation dependence of sapphire substrates. Langmuir 20:4101-4108

51. Khan R, Inam MA, Zam SZ, Park DR, Yeom IT (2018) Assessment of key environmental factors influencing the sedimentation and aggregation behavior of zinc oxide nanoparticles in aquatic environment. Water 10:660

52. Khanna A (2008) Nanotechnology in high performance paint coatings. Asian J Exp Sci 21:25-32

53. Kiser M, Westerhoff $P$, Benn $T$, Wang $Y$, Perez-Rivera J, Hristovski K (2009) Titanium nanomaterial removal and release from wastewater treatment plants. Environ Sci Technol 43:6757-6763

54. Kosmulski M (2004) pH-dependent surface charging and points of zero charge II. Update. J Colloid Interface Sci 275:214-224

55. Kosmulski M (2006) pH-dependent surface charging and points of zero charge: III. Update. J Colloid Interface Sci 298:730-741

56. Kunhikrishnan A, Shon HK, Bolan NS, El Saliby I, Vigneswaran S (2015) Sources, distribution, environmental fate, and ecological effects of nanomaterials in wastewater streams. Crit Rev Environ Sci Technol 45:277-318

57. Lai RW, Yeung KW, Yung MM, Djurišić AB, Giesy JP, Leung KM (2018) Regulation of engineered nanomaterials: current challenges, insights and future directions. Environ Sci Pollu Res 25:3060-3077

58. Landry V, Riedl B, Blanchet P (2008) Alumina and zirconia acrylate nanocomposites coatings for wood flooring: photocalorimetric characterization. Prog Org Coat 61:76-82

59. Le Van N, Ma C, Shang J, Rui Y, Liu S, Xing B (2016) Effects of CuO nanoparticles on insecticidal activity and phytotoxicity in conventional and transgenic cotton. Chemosphere 144:661-670

60. Leitch ME, Casman E, Lowry GV (2012) Nanotechnology patenting trends through an environmental lens: analysis of materials and applications. J Nanopart Res 14:1283

61. Lewis WK, Harruff BA, Gord JR, Rosenberger AT, Sexton TM, Guliants EA, Bunker CE (2010) Chemical dynamics of aluminum nanoparticles in ammonium nitrate and ammonium perchlorate matrices: enhanced reactivity of organically capped aluminum. J Phys Chem C 115:70-77

62. Liu J, Legros S, Von der Kammer F, Hofmann T (2013) Natural organic matter concentration and hydrochemistry influence aggregation kinetics of functionalized engineered nanoparticles. Environ Sci Technol 47:4113-4120

63. Li M, Lin D, Zhu L (2013) Effects of water chemistry on the dissolution of $\mathrm{ZnO}$ nanoparticles and their toxicity to Escherichia coli. Environ Pollut 173:97-102

64. Loosli F, Le Coustumer P, Stoll S (2013) $\mathrm{TiO}_{2}$ nanoparticles aggregation and disaggregation in presence of alginate and Suwannee River humic acids. $\mathrm{pH}$ and concentration effects on nanoparticle stability. Water Res 47:6052-6063

65. Lowry GV, Gregory KB, Apte SC, Lead JR (2012) Transformations of nanomaterials in the environment. ACS Publications, Washington

66. Luo M, Huang $\mathrm{Y}$, Zhu M, Tang Y-N, Ren T, Ren J, Wang H, Li F (2016) Properties of different natural organic matter influence the adsorption and aggregation behavior of $\mathrm{TiO}_{2}$ nanoparticles. J Saudi Chem Soc 22:146-154 
67. Lv X, Gao B, Sun Y, Shi X, Xu H, Wu J (2014) Effects of humic acid and solution chemistry on the retention and transport of cerium dioxide nanoparticles in saturated porous media. Water Air Soil Pollut 225:2167

68. Manusadžianas L, Caillet C, Fachetti L, Gylytė B, Grigutytè R, Jurkoniené S, Karitonas R, Sadauskas K, Thomas F, Vitkus R (2012) Toxicity of copper oxide nanoparticle suspensions to aquatic biota. Environ Toxicol Chem 31:108-114

69. Miao L, Wang C, Hou J, Wang P, Ao Y, Li Y, Geng N, Yao Y, Lv B, Yang $Y$ (2016) Aggregation and removal of copper oxide (CuO) nanoparticles in wastewater environment and their effects on the microbial activities of wastewater biofilms. Bioresour Technol 216:537-544

70. Misra SK, Dybowska A, Berhanu D, Luoma SN, Valsami-Jones E (2012) The complexity of nanoparticle dissolution and its importance in nanotoxicological studies. Sci Total Environ 438:225-232

71. Monikh FA, Praetorius A, Schmid A, Kozin P, Meisterjahn B, Makarova E, Hofmann T, Von Der Kammer F (2018) Scientific rationale for the development of an OECD test guideline on engineered nanomaterial stability. Nanolmpact 11:42-50

72. Mudunkotuwa IA, Rupasinghe T, Wu C-M, Grassian VH (2011) Dissolution of $\mathrm{ZnO}$ nanoparticles at circumneutral $\mathrm{pH}$ : a study of size effects in the presence and absence of citric acid. Langmuir 28:396-403

73. Mueller NC, Nowack B (2008) Exposure modeling of engineered nanoparticles in the environment. Environ Sci Technol 42:4447-4453

74. Mui J, Ngo J, Kim B (2016) Aggregation and colloidal stability of commercially available $\mathrm{Al}_{2} \mathrm{O}_{3}$ nanoparticles in aqueous environments. Nanomaterials 6:90

75. Musee N (2011) Nanotechnology risk assessment from a waste management perspective: are the current tools adequate? Hum Exp Toxicol 30:820-835

76. Musee N (2011) Simulated environmental risk estimation of engineered nanomaterials: a case of cosmetics in Johannesburg City. Hum Exp Toxicol 30:1181-1195

77. Musee N, Zvimba JN, Schaefer LM, Nota N, Sikhwivhilu LM, Thwala M (2014) Fate and behavior of ZnO-and Ag-engineered nanoparticles and a bacterial viability assessment in a simulated wastewater treatment plant. J Environ Sci Health Part A 49:59-66

78. Mwaanga P, Carraway ER, Schlautman MA (2014) Preferential sorption of some natural organic matter fractions to titanium dioxide nanoparticles: influence of $\mathrm{pH}$ and ionic strength. Environ Monit Assess 186:8833-8844

79. Naika HR, Lingaraju K, Manjunath K, Kumar D, Nagaraju G, Suresh D, Nagabhushana H (2015) Green synthesis of CuO nanoparticles using Gloriosa superba L. extract and their antibacterial activity. J Taibah Univ Sci 9:7-12

80. Nason JA, Mcdowell SA, Callahan TW (2012) Effects of natural organic matter type and concentration on the aggregation of citrate-stabilized gold nanoparticles. J Environ Monit 14:1885-1892

81. Nebbioso A, Piccolo A (2013) Molecular characterization of dissolved organic matter (DOM): a critical review. Anal Bioanal Chem 405:109-124

82. Odzak N, Kistler D, Behra R, Sigg L (2014) Dissolution of metal and metal oxide nanoparticles in aqueous media. Environ Pollut 191:132-138

83. Omar FM, Aziz HA, Stoll S (2014) Aggregation and disaggregation of $\mathrm{ZnO}$ nanoparticles: influence of $\mathrm{pH}$ and adsorption of Suwannee River humic acid. Sci Total Environ 468:195-201

84. Ottofuelling S, Von Der Kammer F, Hofmann T (2011) Commercial titanium dioxide nanoparticles in both natural and synthetic water: comprehensive multidimensional testing and prediction of aggregation behavior. Environ Sci Technol 45:10045-10052

85. Pakrashi S, Dalai S, Prathna T, Trivedi S, Myneni R, Raichur AM, Chandrasekaran N, Mukherjee A (2013) Cytotoxicity of aluminium oxide nanoparticles towards fresh water algal isolate at low exposure concentrations. Aquat Toxicol 132:34-45

86. Pakrashi S, Dalai S, Sneha B, Chandrasekaran N, Mukherjee A (2012) A temporal study on fate of $\mathrm{Al}_{2} \mathrm{O}_{3}$ nanoparticles in a fresh water microcosm at environmentally relevant low concentrations. Ecotoxicol Environ Saf 84:70-77

87. Peng C, Shen C, Zheng S, Yang W, Hu H, Liu J, Shi J (2017) Transformation of $\mathrm{CuO}$ nanoparticles in the aquatic environment: influence of $\mathrm{pH}$. Electrolytes and natural organic matter. Nanomaterials 7:326

88. Peters RJ, Van Bemmel G, Milani NB, Den Hertog GC, Undas AK, Van Der Lee M, Bouwmeester H (2018) Detection of nanoparticles in Dutch surface waters. Sci Total Environ 621:210-218

89. Philippe A, Schaumann GE (2014) Interactions of dissolved organic matter with natural and engineered inorganic colloids: a review. Environ Sci Technol 48:8946-8962

90. Piccinno F, Gottschalk F, Seeger S, Nowack B (2012) Industrial production quantities and uses of ten engineered nanomaterials in Europe and the world. J Nanopart Res 14:1109

91. Piriyawong V, Thongpool V, Asanithi P, Limsuwan P (2012) Preparation and characterization of alumina nanoparticles in deionized water using laser ablation technique. J Nanomater 2012

92. Prashanth $P$, Raveendra R, Hari Krishna R, Ananda S, Bhagya N, Nagabhushana B, Lingaraju K, Raja Naika H (2015) Synthesis, characterizations, antibacterial and photoluminescence studies of solution combustion-derived $\mathrm{a}-\mathrm{Al}_{2} \mathrm{O}_{3}$ nanoparticles. J Asian Ceram Soc 3:345-351

93. Romanello MB, De Cortalezzi MMF (2013) An experimental study on the aggregation of $\mathrm{TiO}_{2}$ nanoparticles under environmentally relevant conditions. Water Res 47:3887-3898

94. Sadiq IM, Pakrashi S, Chandrasekaran N, Mukherjee A (2011) Studies on toxicity of aluminum oxide $\left(\mathrm{Al}_{2} \mathrm{O}_{3}\right)$ nanoparticles to microalgae species: scenedesmus sp. and Chlorella sp. J Nanopart Res 13:3287-3299

95. Sikder M, Lead JR, Chandler GT, Baalousha M (2018) A rapid approach for measuring silver nanoparticle concentration and dissolution in seawater by UV-Vis. Sci Total Environ 618:597-607

96. Slomberg DL, Ollivier P, Miche $H$, Angeletti B, Bruchet A, Philibert M, Brant J, Labille J (2019) Nanoparticle stability in lake water shaped by natural organic matter properties and presence of particulate matter. Sci Total Environ 656:338-346

97. Son DI, You CH, Kim TW (2009) Structural, optical, and electronic properties of colloidal CuO nanoparticles formed by using a colloid-thermal synthesis process. Appl Surf Sci 255:8794-8797

98. Son J, Vavra J, Forbes VE (2015) Effects of water quality parameters on agglomeration and dissolution of copper oxide nanoparticles (CuO-NPs) using a central composite circumscribed design. Sci Total Environ 521:183-190

99. Sousa VS, Teixeira MR (2013) Aggregation kinetics and surface charge of $\mathrm{CuO}$ nanoparticles: the influence of $\mathrm{pH}$, ionic strength and humic acids. Environ Chem 10:313-322

100. Studer AM, Limbach LK, Van Duc L, Krumeich F, Athanassiou EK, Gerber LC, Moch H, Stark WJ (2010) Nanoparticle cytotoxicity depends on intracellular solubility: comparison of stabilized copper metal and degradable copper oxide nanoparticles. Toxicol Lett 197:169-174

101. Talling $J(2010)$ Potassium - a non-limiting nutrient in fresh waters? Freshw Rev 3:97-104 
102. Thio BJR, Zhou D, Keller AA (2011) Influence of natural organic matter on the aggregation and deposition of titanium dioxide nanoparticles. J Hazard Mater 189:556-563

103. Thit A, Huggins K, Selck H, Baun A (2017) Acute toxicity of copper oxide nanoparticles to Daphnia magna under different test conditions. Toxicol Environ Chem 99:665-679

104. Thwala M, Klaine SJ, Musee N (2016) Interactions of metalbased engineered nanoparticles with aquatic higher plants: a review of the state of current knowledge. Environ Toxicol Chem 35:1677-1694

105. Thwala M, Musee N, Sikhwivhilu L, Wepener V (2013) The oxidative toxicity of $\mathrm{Ag}$ and $\mathrm{ZnO}$ nanoparticles towards the aquatic plant Spirodela punctuta and the role of testing media parameters. Environ Sci Process Impacts 15:1830-1843

106. Van Hoecke K, De Schamphelaere KA, Van Der Meeren P, Smagghe $G$, Janssen CR (2011) Aggregation and ecotoxicity of $\mathrm{CeO}_{2}$ nanoparticles in synthetic and natural waters with variable $\mathrm{pH}$, organic matter concentration and ionic strength. Environ Pollut 159:970-976

107. Van Koetsem F, Xiao Y, Luo Z, Du Laing G (2016) Impact of water composition on association of $\mathrm{Ag}$ and $\mathrm{CeO}_{2}$ nanoparticles with aquatic macrophyte Elodea canadensis. Environ Sci Pollut Res 23:5277-5287

108. Vidya P, Chitra K (2017) Assessment of acute toxicity (LC5096h) of aluminium oxide, silicon dioxide and titanium dioxide nanoparticles on the freshwater fish, Oreochromis mossambicus (Peters, 1852). Int J Fish Aquat Stud 5:327-332

109. Wang D, Gao Y, Lin Z, Yao Z, Zhang W (2014) The joint effects on Photobacterium phosphoreum of metal oxide nanoparticles and their most likely coexisting chemicals in the environment. Aquat Toxicol 154:200-206

110. Wang H, Zhao X, Han X, Tang Z, Liu S, Guo W, Deng C, Guo $\mathrm{Q}$, Wang $\mathrm{H}$, Wu $\mathrm{F}$ (2017) Effects of monovalent and divalent metal cations on the aggregation and suspension of $\mathrm{Fe}_{3} \mathrm{O}_{4}$ magnetic nanoparticles in aqueous solution. Sci Total Environ 586:817-826

111. Wang Z, Li J, Zhao J, Xing B (2011) Toxicity and internalization of CuO nanoparticles to prokaryotic alga Microcystis aeruginosa as affected by dissolved organic matter. Environ Sci Technol 45:6032-6040

112. Wang Z, Zhang K, Zhao J, Liu X, Xing B (2010) Adsorption and inhibition of butyrylcholinesterase by different engineered nanoparticles. Chemosphere 79:86-92

113. Wang Z, Zhang L, Zhao J, Xing B (2016) Environmental processes and toxicity of metallic nanoparticles in aquatic systems as affected by natural organic matter. Environ Sci Nano 3:240-255

114. Wilke CM, Tong T, Gaillard J-FO, Gray KA (2016) Attenuation of microbial stress due to Nano-Ag and nano- $\mathrm{TiO}_{2}$ interactions under dark conditions. Environ Sci Technol 50:11302-11310

115. Wilkinson KJ, Joz-Roland A, Buffle J (1997) Different roles of pedogenic fulvic acids and aquagenic biopolymers on colloid aggregation and stability in freshwaters. Limnol Oceanogr 42:1714-1724

116. Wong K-FV, Kurma T (2008) Transport properties of alumina nanofluids. Nanotechnology 19:345702
117. Xiao Y, Vijver MG, Peijnenburg WJ (2018) Impact of water chemistry on the behavior and fate of copper nanoparticles. Environ Pollut 234:684-691

118. Yang K, Lin D, Xing B (2009) Interactions of humic acid with nanosized inorganic oxides. Langmuir 25:3571-3576

119. Yang L, Wang W-X (2019) Comparative contributions of copper nanoparticles and ions to copper bioaccumulation and toxicity in barnacle larvae. Environ Pollut 249:116-124

120. Yang Y, Long C-L, Li H-P, Wang Q, Yang Z-G (2016) Analysis of silver and gold nanoparticles in environmental water using single particle-inductively coupled plasma-mass spectrometry. Sci Total Environ 563:996-1007

121. Ye N, Wang Z, Fang H, Wang S, Zhang F (2017) Combined ecotoxicity of binary zinc oxide and copper oxide nanoparticles to Scenedesmus obliquus. J Environ Sci Health Part A 52:555-560

122. Ye N, Wang Z, Wang S, Fang H, Wang D (2018) Aqueous aggregation and stability of graphene nanoplatelets, graphene oxide, and reduced graphene oxide in simulated natural environmental conditions: complex roles of surface and solution chemistry. Environ Sci Pollut Res 25:10956-10965

123. Ye N, Wang Z, Wang S, Fang H, Wang D (2018) Dissolved organic matter and aluminum oxide nanoparticles synergistically cause cellular responses in freshwater microalgae. J Environ Sci Health Part A 53:651-658

124. Yu S, Liu J, Yin Y, Shen M (2017) Interactions between engineered nanoparticles and dissolved organic matter: a review on mechanisms and environmental effects. J Environ Sci 63:198-217

125. Zhang $Y$, Chen $Y$, Westerhoff $P$, Crittenden J (2009) Impact of natural organic matter and divalent cations on the stability of aqueous nanoparticles. Water Res 43:4249-4257

126. Zhang Y, Chen Y, Westerhoff $P$, Hristovski K, Crittenden JC (2008) Stability of commercial metal oxide nanoparticles in water. Water Res 42:2204-2212

127. Zhao J, Wang Z, Dai Y, Xing B (2013) Mitigation of CuO nanoparticle-induced bacterial membrane damage by dissolved organic matter. Water Res 47:4169-4178

128. Zheng X, Wu R, Chen Y (2011) Effects of ZnO nanoparticles on wastewater biological nitrogen and phosphorus removal. Environ Sci Technol 45:2826-2832

129. Zhu X, Zhu L, Chen Y, Tian S (2009) Acute toxicities of six manufactured nanomaterial suspensions to Daphnia magna. J Nanopart Res 11:67-75

130. Zook JM, Rastogi V, Maccuspie Rl, Keene AM, Fagan J (2011) Measuring agglomerate size distribution and dependence of localized surface plasmon resonance absorbance on gold nanoparticle agglomerate size using analytical ultracentrifugation. ACS Nano 5:8070-8079

Publisher's Note Springer Nature remains neutral with regard to jurisdictional claims in published maps and institutional affiliations. 